\title{
Comparability of River Suspended-Sediment Sampling and Laboratory Analysis Methods
}

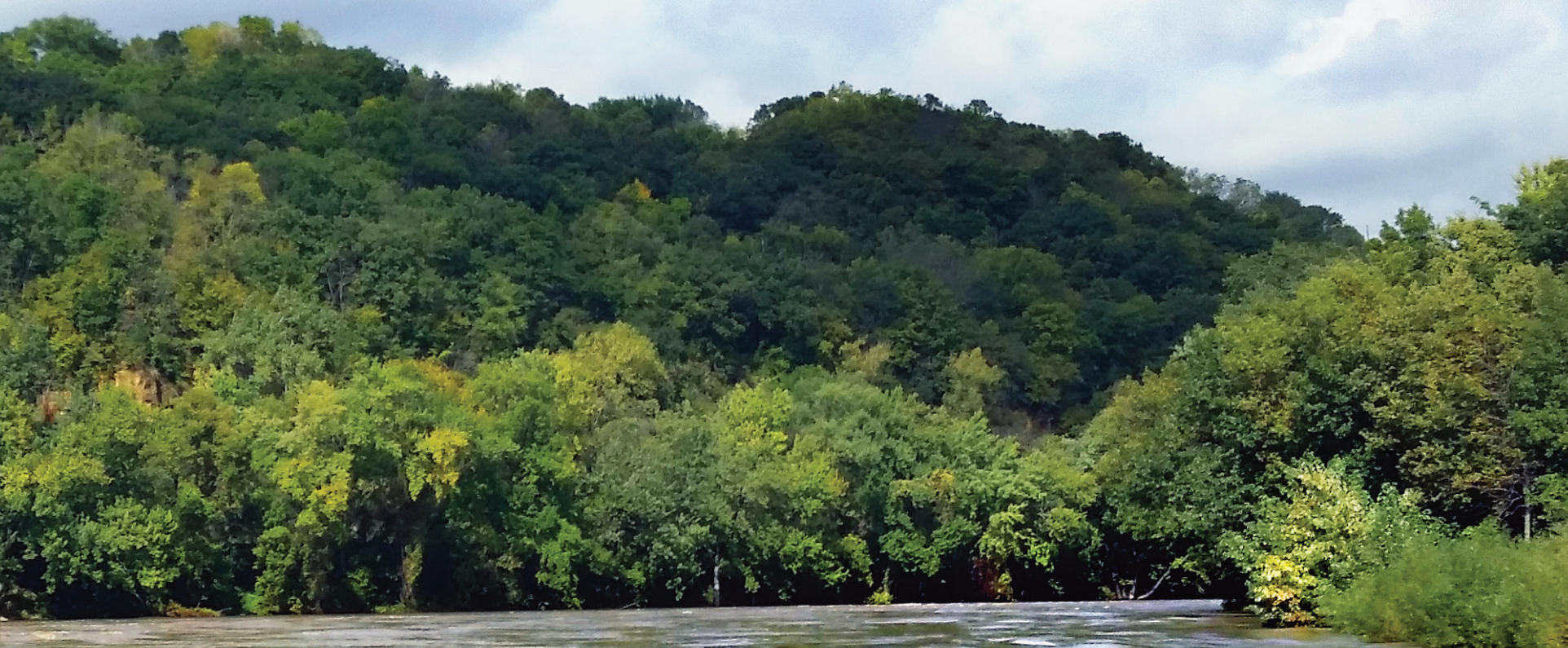

Scientific thvestigations Report 2018-5023

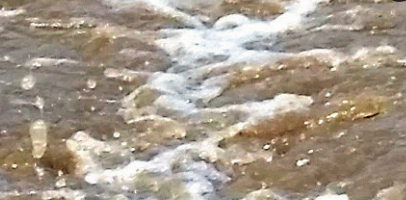

USDepartment of the interior?

us. teqlogical survey
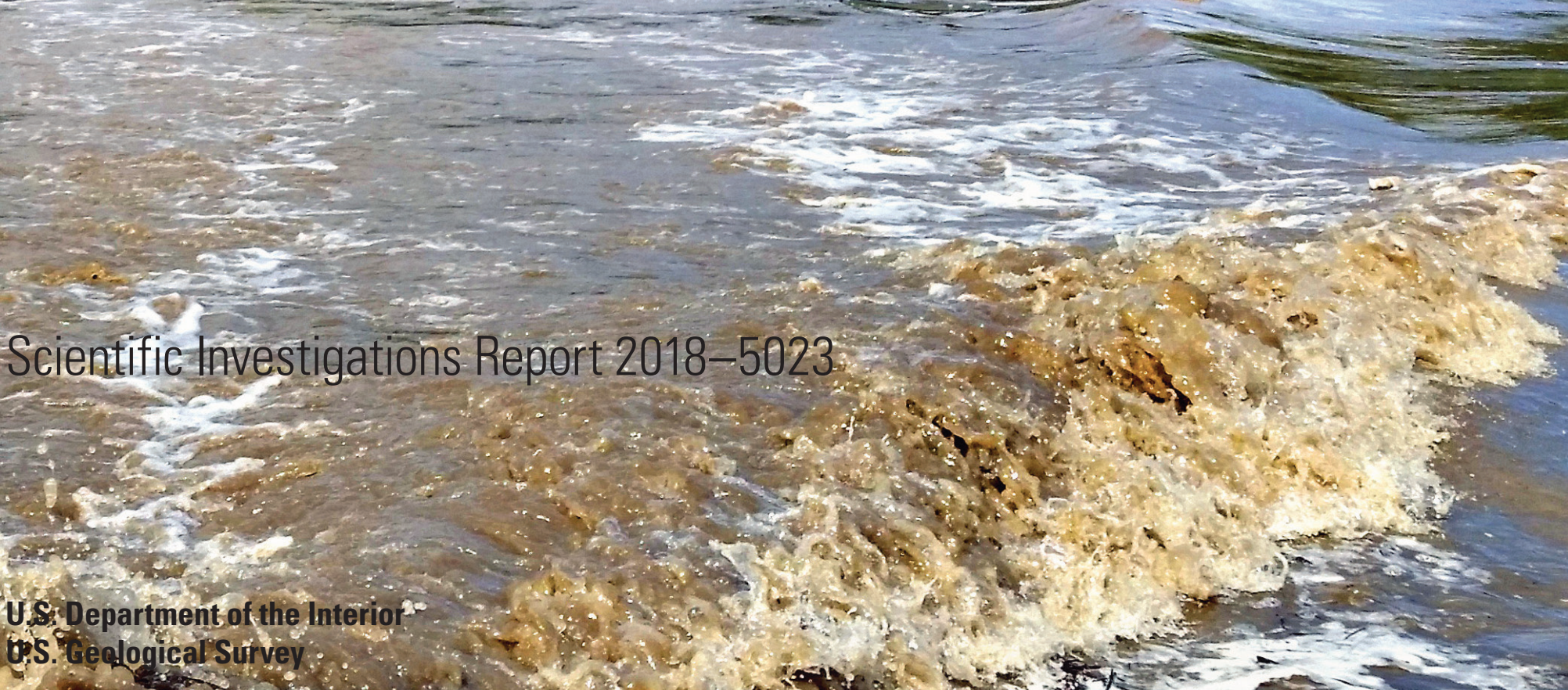
Cover. The Blue Earth River looking downstream at the confluence with the Minnesota River in Mankato, Minnesota (photograph by J. William Lund, U.S. Geological Survey). 


\section{Comparability of River Suspended- Sediment Sampling and Laboratory Analysis Methods}

By Joel T. Groten and Gregory D. Johnson

Prepared in collaboration with the Minnesota Pollution Control Agency,

Clean Water Fund

Scientific Investigations Report 2018-5023 


\title{
U.S. Department of the Interior \\ RYAN K. ZINKE, Secretary
}

\section{U.S. Geological Survey William H. Werkheiser, Deputy Director exercising the authority of the Director}

\author{
U.S. Geological Survey, Reston, Virginia: 2018
}

For more information on the USGS - the Federal source for science about the Earth, its natural and living resources, natural hazards, and the environment-visit https://www.usgs.gov or call 1-888-ASK-USGS.

For an overview of USGS information products, including maps, imagery, and publications, visit https://store.usgs.gov.

Any use of trade, firm, or product names is for descriptive purposes only and does not imply endorsement by the U.S. Government.

Although this information product, for the most part, is in the public domain, it also may contain copyrighted materials as noted in the text. Permission to reproduce copyrighted items must be secured from the copyright owner.

Suggested citation:

Groten, J.T., and Johnson, G.D., 2018, Comparability of river suspended-sediment sampling and laboratory analysis methods: U.S. Geological Survey Scientific Investigations Report 2018-5023, 23 p., https://doi.org/10.3133/ sir20185023.

ISSN 2328-0328 (online) 


\section{Contents}

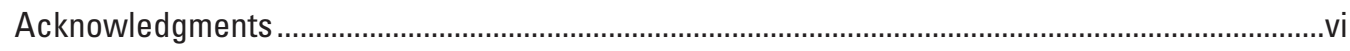

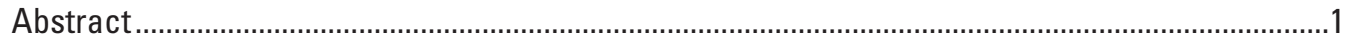

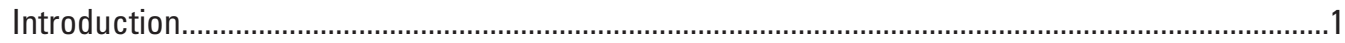

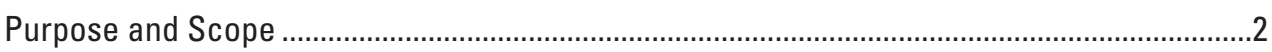

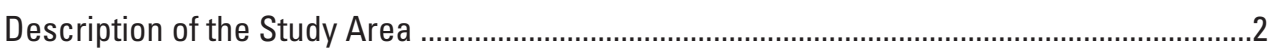

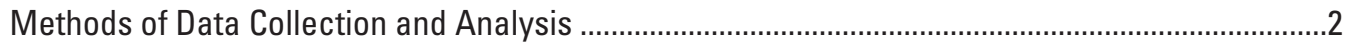

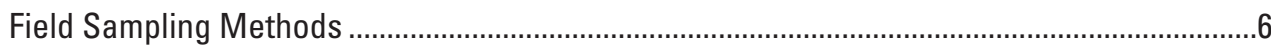

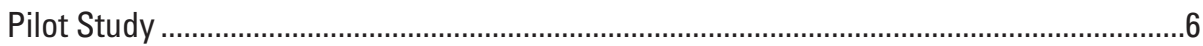

Grab Field Sampling ....................................................................................................

Equal-Width-Increment or Equal-Discharge-Increment Field Sampling ........................6

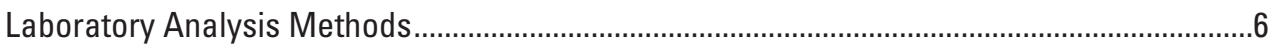

Total Suspended Solids Laboratory Analysis Method ........................................................6

Suspended-Sediment Concentration Laboratory Analysis Method .................................6

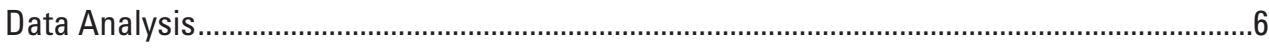

Field Sampling and Laboratory Analysis Method Comparison ............................................................7

Effect of Particle Size on Sampling and Laboratory Analysis Methods ...................................15

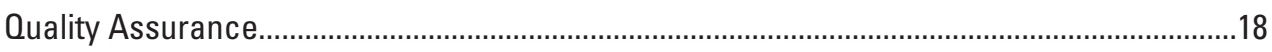

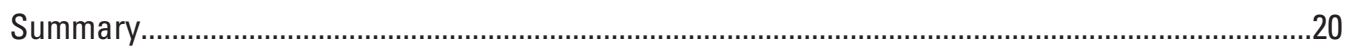

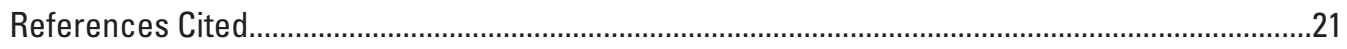

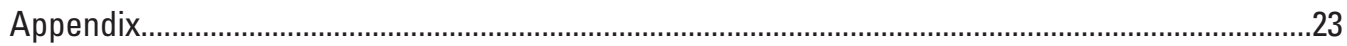




\section{Figures}

1. Map showing selected sediment monitoring sites, contributing basins, and hillshade of the landscape relief in Minnesota

2. Graphs showing streamflow and collection dates of suspended-sediment samples at eight sediment monitoring sites in Minnesota, water year 2016

3. Infographic demonstrating five combinations of field sampling and laboratory analysis methods used to compare differences in sediment concentrations

4. Box plots for grab samples, equal-width-increment or equal-discharge-increment samples, total suspended solids, suspended-sediment concentrations, and percent fines data at eight sites in Minnesota, water year 2016

5. Graphs showing relations between different field sampling and laboratory analysis methods, field sampling methods, and laboratory analysis methods in Minnesota, water year 2016

6. Graphs showing sand-sized particles effect on relations between different field sampling and laboratory analysis methods, field sampling methods, and laboratory analysis methods in Minnesota, water year 2016.

\section{Tables}

1. Selected sediment monitoring sites in Minnesota, water year 2016.

2. Grab, equal-width-increment or equal-discharge-increment, total suspended solids, and suspended-sediment concentration data at eight sites in Minnesota, water year 2016

3. Suspended-sediment concentration outliers, water year 2016

4. Summary statistics for grab sampling, equal-width-increment or equal-discharge-increment sampling, total suspended solids, suspended-sediment concentrations, and percent fines at eight sites in Minnesota, water year 2016.

5. Summary of Wilcoxon signed-rank tests used to evaluate differences between field sampling and laboratory analysis method combinations in Minnesota, water year 2016

6. Summary of simple linear regression models to evaluate field sampling and laboratory analysis method combinations in Minnesota, water year 2016

7. Summary of simple linear regression models to evaluate effect of sand-sized particles on field sampling and laboratory analysis method combinations in Minnesota, water year 2016

8. Results of quality-assurance samples for suspended-sediment concentration for samples collected at selected sites in Minnesota, water year 2016

9. Results of quality assurance for the total suspended solids laboratory analysis method at two laboratories, water year 2016 


\section{Conversion Factors}

International System of Units to U.S. customary units

\begin{tabular}{lll}
\hline \multicolumn{1}{c}{ Multiply } & By & \multicolumn{1}{c}{ To obtain } \\
\hline millimeter $(\mathrm{mm})$ & Length & \\
centimeter $(\mathrm{cm})$ & 0.03937 & inch (in.) \\
meter $(\mathrm{m})$ & 0.3937 & inch (in.) \\
\hline & 1.094 & yard (yd) \\
\hline square kilometer $\left(\mathrm{km}^{2}\right)$ & Area & square mile (mi $)$ \\
\hline & 0.3861 & \\
\hline liter $(\mathrm{L})$ & Volume & ounce, fluid (fl. oz) \\
\hline
\end{tabular}

\section{Supplemental Information}

Concentrations of constituents in water are given in milligrams per liter $(\mathrm{mg} / \mathrm{L})$.

Water year (WY) is the 12-month period, October 1 through September 30, and is designated by the calendar year in which it ends.

\section{Abbreviations}

$\begin{array}{ll}\text { ASTM } & \text { American Society for Testing and Material } \\ \text { EWDI } & \text { equal-width-increment or equal-discharge-increment } \\ \text { MDH } & \text { Minnesota Department of Health } \\ \text { MNDNR } & \text { Minnesota Department of Natural Resources } \\ \text { MPCA } & \text { Minnesota Pollution Control Agency } \\ \text { PD } & \text { percent difference } \\ p \text {-value } & \text { probability value } \\ \text { RPD } & \text { relative percent difference } \\ R^{2} & \text { coefficient of determination } \\ \text { SLR } & \text { simple linear regression } \\ \text { SSC } & \text { suspended-sediment concentration } \\ \text { TSS } & \text { total suspended solids } \\ \text { USGS } & \text { U.S. Geological Survey } \\ \text { WY } & \text { water year }\end{array}$




\section{Acknowledgments}

This report presents a compilation of information supplied by many agencies and individuals. The authors would like to thank the Minnesota Pollution Control Agency, Clean Water Fund, Minnesota Department of Natural Resources, and the Environment and Natural Resources Trust Fund for their assistance with this study.

Gerald Storey, J. William Lund, Joshua Ayers, Lindsay Hastings, Brent Mason, and Trent Sherman of the U.S. Geological Survey and Samuel Barsanelli Costa of the Institute for Technological Research, Sao Paulo, Brazil are acknowledged for assistance with data collection and report preparation. Christopher Ellison and Erik Smith of the U.S. Geological Survey are acknowledged for their technical reviews of the report. 


\title{
Comparability of River Suspended-Sediment Sampling and Laboratory Analysis Methods
}

\author{
By Joel T. Groten ${ }^{1}$ and Gregory D. Johnson ${ }^{2}$
}

\section{Abstract}

Accurate measurements of suspended sediment, a leading water-quality impairment in many Minnesota rivers, are important for managing and protecting water resources; however, water-quality standards for suspended sediment in Minnesota are based on grab field sampling and total suspended solids (TSS) laboratory analysis methods that have underrepresented concentrations of suspended sediment in rivers compared to U.S. Geological Survey equal-widthincrement or equal-discharge-increment (EWDI) field sampling and suspended sediment concentration (SSC) laboratory analysis methods. Because of this underrepresentation, the U.S. Geological Survey, in collaboration with the Minnesota Pollution Control Agency, collected concurrent grab and EWDI samples at eight sites to compare results obtained using different combinations of field sampling and laboratory analysis methods.

Study results determined that grab field sampling and TSS laboratory analysis results were biased substantially low compared to EWDI sampling and SSC laboratory analysis results, respectively. Differences in both field sampling and laboratory analysis methods caused grab and TSS methods to be biased substantially low. The difference in laboratory analysis methods was slightly greater than field sampling methods.

Sand-sized particles had a strong effect on the comparability of the field sampling and laboratory analysis methods. These results indicated that grab field sampling and TSS laboratory analysis methods fail to capture most of the sand being transported by the stream. The results indicate there is less of a difference among samples collected with grab field sampling and analyzed for TSS and concentration of fines in SSC. Even though differences are present, the presence of strong correlations between SSC and TSS concentrations provides the opportunity to develop site specific relations to address transport processes not captured by grab field sampling and TSS laboratory analysis methods.

${ }^{1}$ U.S. Geological Survey.

${ }^{2}$ Minnesota Pollution Control Agency.

\section{Introduction}

Excess suspended sediment can impair rivers by adversely affecting aquatic habitat, degrading water quality, transporting harmful contaminants, diminishing recreational opportunities, and depositing sediment in navigable waterways (U.S. Army Corps of Engineers, 2006; Minnesota Pollution Control Agency [MPCA], 2009). Reliable, consistent suspended-sediment data are imperative to address remediation efforts of river sediment impairments. Currently (2018), the U.S. Environmental Protection Agency and many State water-quality agencies use surface grab samples and the total suspended solids (TSS) laboratory analysis method to compare stream conditions to water-quality standards for suspended sediment (Pat Baskfield, MPCA, oral commun., May 22, 2017); however, previous studies indicated that estimates of suspended sediment obtained using these protocols substantially underestimated suspended sediment compared to standard U.S. Geological Survey (USGS) equal-width-increment or equal-discharge-increment (EWDI) and suspendedsediment concentration (SSC) laboratory analysis methods (Gray and others, 2000; Ellison and others, 2014). Because previous studies compared data obtained using two protocols that included different field sampling and laboratory analysis methods, the exact cause of observed differences could not be determined; therefore, the USGS, in collaboration with the MPCA, completed a study designed using multiple combinations of field sampling and laboratory analysis methods to evaluate how differences in these methods affect suspended sediment results.

Grab samples are typically collected in the centroid of a stream channel, within 1 meter of the water surface. Conversely, water samples collected by USGS methods are collected and composited from multiple locations across the stream using isokinetic samplers and depth-and-width-integration methods described by Ward and Harr (1990), Edwards and Glysson (1999), and Davis and the Federal Interagency Sedimentation Project (2005). The use of these data collection methods provides a vertically and laterally discharge-weighted composite sample that is intended to be representative of the entire flow passing through the cross section of a stream. 
The TSS laboratory analysis method typically is used in conjunction with a grab sample. For the TSS laboratory analysis method, a subsample of the original water sample is extracted and filtered to measure the amount of suspended material (Clesceri and others, 1998); however, according to Gray and others (2000), the subsample may not be representative of the whole water sample. In addition, if suspended sediment is not homogenous throughout the stream channel, the grab sample likely will not accurately represent the suspended sediment present in the entire stream channel.

In contrast, the SSC laboratory analysis method used by the USGS measures the whole water sample containing the entire amount of suspended material in the original sample (Guy, 1969; American Society for Testing and Material [ASTM], 2000; USGS, variously dated). A study comparing TSS and SSC in Minnesota streams demonstrated that TSS underestimated SSC median values by about 50 percent (Ellison and others, 2014). In addition, Gray and others (2000) indicated that negative biases in TSS results compared to SSC results are exacerbated when samples consist of more than 25 percent sand-sized particles (Gray and others, 2000); therefore, additional study is required to determine the causes and magnitudes of differences between TSS and SSC.

\section{Purpose and Scope}

The purpose of this report is to summarize and interpret river suspended-sediment data collected using different field sampling methods (grab and EWDI) and analyzed using different laboratory methods (TSS, SSC, and particle sizes) during water year (WY) 2016 at eight selected sediment monitoring sites (fig. 1; table 1) in Minnesota. Specifically, the report (1) quantifies the variation among different combinations of field sampling and laboratory analysis methods, (2) describes the effects of sand-sized particles on field sampling and laboratory analysis methods, and (3) develops relations between field sampling and laboratory analysis methods. A water year is the 12-month period October 1 through September 30 designated by the calendar year in which it ends.

\section{Description of the Study Area}

The eight sediment monitoring sites selected for this study represent different basins (fig. 1; table 1) and suspendedsediment characteristics present in Minnesota. A map of Minnesota shows the sediment monitoring sites, the contributing basins, and a hillshade of the landscape relief (fig. 1). Sediment monitoring sites (table 1) were collocated at either USGS streamgages, available at https:/waterdata.usgs.gov/ nwis (USGS, 2017a), or Minnesota Department of Natural Resources (MNDNR) and MPCA cooperative streamgages (table 1), available at http:/www.dnr.state.mn.us/waters/ csg/index.html (MNDNR, 2017). The MNDNR and MPCA cooperative streamgages (table 1) included in this study are part of the MPCA Watershed Pollutant Load Network (MPCA, 2017b).

\section{Methods of Data Collection and Analysis}

Water samples were collected for analyses of TSS, SSC, and particle sizes at eight sediment monitoring sites (fig. 1; table 1) in WY 2016. All samples were collected during the open-water season (March 1 through September 30; fig. 2). SSC samples were collected over a wide range of streamflow conditions (USGS, 2017a; MNDNR, 2017). The position of the samples along the streamflow hydrograph for each site is shown on figure 2.

Table 1. Selected sediment monitoring sites in Minnesota, water year 2016.

[USGS, U.S. Geological Survey; Minn., Minnesota; MNDNR, Minnesota Department of Natural Resources; MPCA, Minnesota Pollution Control Agency]

\begin{tabular}{lccccc}
\hline \multicolumn{1}{c}{ Station name } & $\begin{array}{c}\text { USGS } \\
\text { station } \\
\text { number }\end{array}$ & $\begin{array}{c}\text { Responsible } \\
\text { for streamgage } \\
\text { operation }\end{array}$ & $\begin{array}{r}\text { Latitude } \\
\text { (North) }\end{array}$ & $\begin{array}{c}\text { Longitude } \\
\text { (West) }\end{array}$ & $\begin{array}{c}\text { Drainage } \\
\text { area } \\
\text { (square } \\
\text { kilometers) }\end{array}$ \\
\hline Knife River near Two Harbors, Minn. & 04015330 & USGS & 46.94694 & -91.79222 & 218 \\
Clearwater River at Plummer, Minn. & 05078000 & USGS & 47.92333 & -96.04611 & 1,434 \\
Sauk River near St. Cloud, Minn. & 05270500 & USGS & 45.55972 & -94.23333 & 2,685 \\
Redwood River near Marshall, Minn. & 05315000 & USGS & 44.43027 & -95.82937 & 672 \\
Blue Earth River at Highway 169 at Mankato, Minn. & 05321995 & USGS & 44.09156 & -94.01596 & 9,194 \\
Minnesota River at County Highway 22 in Saint Peter, Minn. & 05325300 & MNDNR/MPCA & 44.30750 & -93.95008 & 39,098 \\
Zumbro River at Kellogg, Minn. & 05374900 & MNDNR/MPCA & 44.31194 & -92.00389 & 3,626 \\
Root River at County Highway 25 near Mound Prairie, Minn. & 05386070 & MNDNR/MPCA & 43.78136 & -91.44647 & 4,120 \\
\hline
\end{tabular}




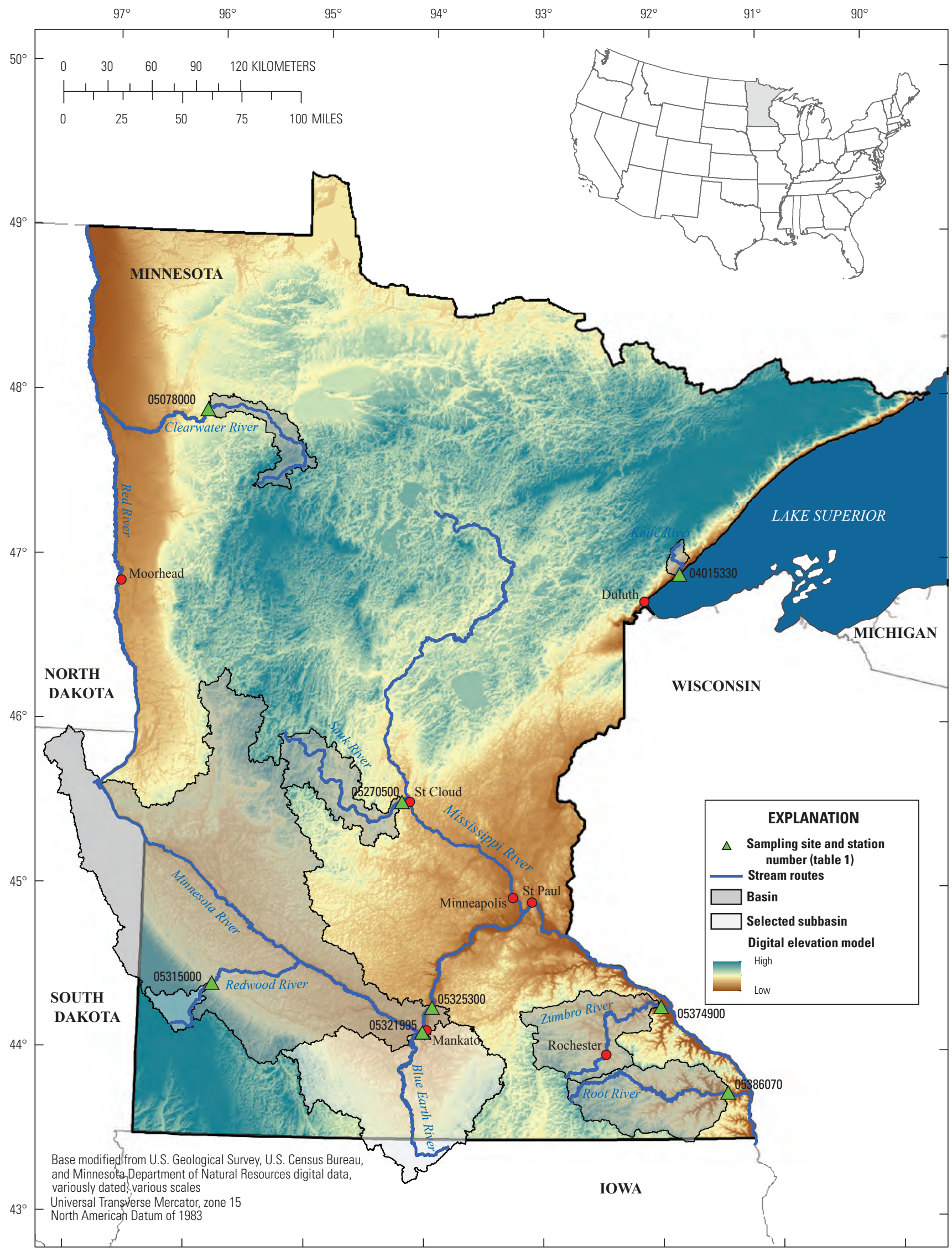

Figure 1. Selected sediment monitoring sites, contributing basins, and hillshade of the landscape relief in Minnesota. 

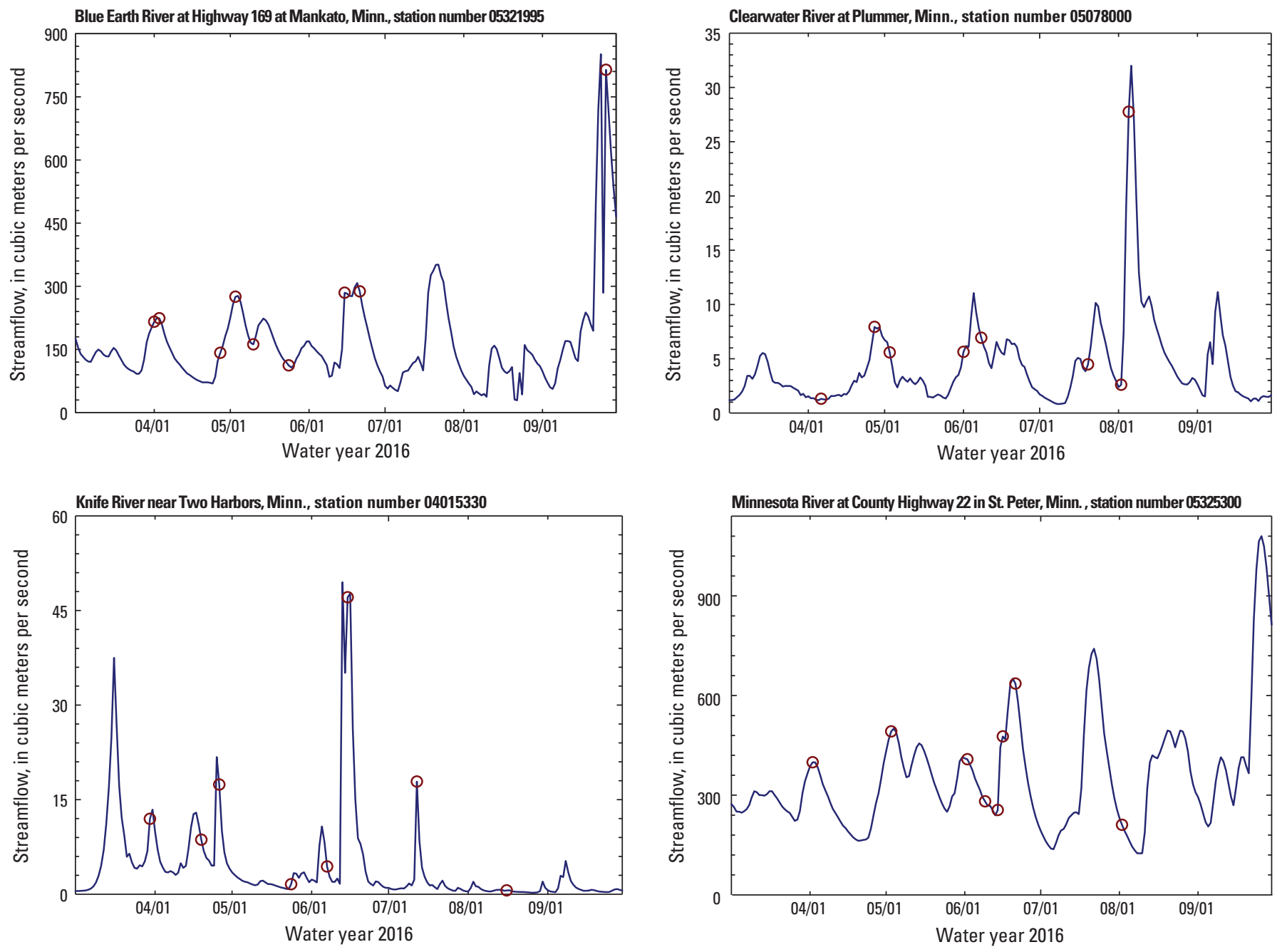

EXPLANATION

- Streamflow O Sample collection

Figure 2. Streamflow and collection dates of suspended-sediment samples at eight sediment monitoring sites (fig. 1; table 1) in Minnesota, water year 2016. 

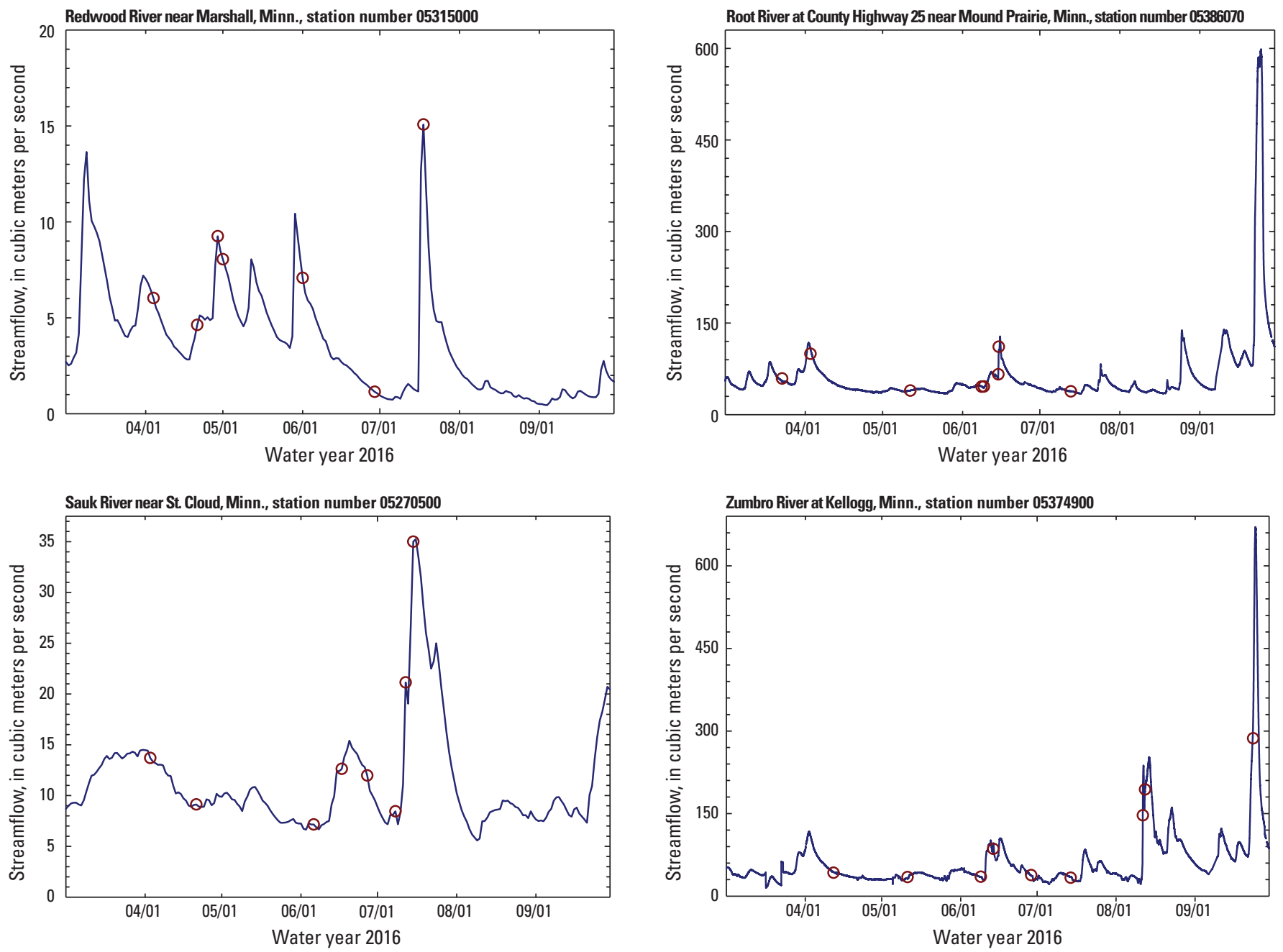

EXPLANATION

Figure 2. Streamflow and collection dates of suspended-sediment samples at eight sediment monitoring sites (fig. 1; table 1) in Minnesota, water year 2016. - Continued 
The differences attributable to field sampling methods can be determined by concurrently collecting water samples with grab and EWDI field sampling methods and analyzing those two samples with the same laboratory analysis method (SSC or TSS). This isolated the differences caused by field sampling methods. Conversely, differences in laboratory analysis methods were determined by comparing the concurrent water samples that were collected with the same field sampling method (EWDI or grab) and analyzing one sample for TSS and one sample for SSC. This isolated the difference caused by laboratory analysis methods.

\section{Field Sampling Methods}

Water samples were collected concurrently using grab and isokinetic, EWDI sampling methods (Edwards and Glysson, 1999) to provide four samples at each sampling visit. Four samples were collected at each sediment monitoring site consisting of two concurrent grab samples and two concurrent EWDI samples. Concurrent sample collection methods were used to eliminate concerns raised by a 2015 pilot study completed in Minnesota regarding uncertainties with using a churn splitter to provide paired subsamples for laboratory analysis.

\section{Pilot Study}

A churn splitter to field-process water samples is not recommended when SSC values are greater than 10,000 milligrams per liter $(\mathrm{mg} / \mathrm{L})$ because its usage is not representative of the stream and the sample variance is inordinately large (USGS, 1997; Wilde and others, 1999). All the samples obtained in a WY 2015 pilot study were below the $10,000 \mathrm{mg} / \mathrm{L}$ threshold; however, preliminary results have indicated that the subsample from the churn splitter is not representative of the original sample at values less than $10,000 \mathrm{mg} / \mathrm{L}$, and a churn splitter is not recommended (Mark Landers, USGS, oral commun., March 21, 2016). The insights garnered from the 2015 pilot study led to a modified sampling plan designed to reduce potential variance, bias introduced from using the churn splitter, or both. The modification to the WY 2016 sampling plan entailed not using the churn splitter.

\section{Grab Field Sampling}

A grab sample was collected using a 1-liter high-density polyethylene bottle secured inside of a weighted-bottle sampler (US WBH-96, Rickly Hydrological Co., Inc., Columbus, Ohio). The grab sample was collected from the centroid of the river channel at a depth less than 1 meter below the water surface. Two grab samples were collected concurrently at the beginning of EWDI field sampling.

\section{Equal-Width-Increment or Equal-Discharge- Increment Field Sampling}

Isokinetic and depth-integrated samples were collected at EWDIs (Edwards and Glysson, 1999). Most of the samples were collected using the equal-width-increment field sampling method (Edwards and Glysson, 1999). At each sample point, two separate samples were collected concurrently. Concurrent field sampling was done at each vertical throughout the stream cross section.

\section{Laboratory Analysis Methods}

The environmental laboratory at the Minnesota Department of Health (MDH) in Saint Paul, Minnesota, and the USGS Sediment Laboratory in Iowa City, Iowa, were used to analyze collected samples. The two laboratory analysis methods were TSS and SSC.

\section{Total Suspended Solids Laboratory Analysis Method}

TSS was analyzed at two laboratories. One grab sample from each sampling event was sent to the MDH Environmental Laboratory and analyzed for TSS following method 2540 D (Clesceri and others, 1998) to determine the concentration of each sample. One EWDI from each sampling event was sent to the USGS Sediment Laboratory and analyzed for TSS following the same method (Julie Nason, USGS, oral commun., May 22, 2016).

\section{Suspended-Sediment Concentration Laboratory Analysis Method}

One grab and one EWDI sample from each sampling event were analyzed for SSC following method D3977-97 (Guy, 1969; ASTM, 2000) by the USGS Sediment Laboratory. The percentage of fines (particle sizes less than 0.0625 millimeter [mm]) also was determined for each SSC sample (Guy, 1969) at the same laboratory.

\section{Data Analysis}

Field sampling and laboratory analysis method abbreviations will be combined in the following sections of the report to describe the combined field sampling and laboratory analysis methods used for each value or group of values; for example, the field sampling method abbreviation (Grab or EWDI) describes a sample collected in the field by grab or EWDI sampling methods and will come first, followed by an 
en dash (-), and followed by the laboratory analysis method abbreviation (TSS or SSC), which describes the laboratory analysis method used. EWDI-SSC was considered the most representative field sampling and laboratory analysis method combination, so it was the reference value from which a result obtained from any other method would be compared. Data analyses included the computation of summary statistics, Wilcoxon signed-rank test (Helsel and Hirsch, 2002), simple linear regression (SLR) analysis, percent difference (PD; Ellison and others, 2014), and relative percent difference (RPD; Ellison and others, 2014). Data used in analyses are presented in table 2; data also are available at https://waterdata.usgs.gov/ nwis (U.S. Geological Survey, 2017a) and at https://www.pca. state.mn.us/environmental-data (MPCA, 2017a).

Data were normalized with a logarithm transformation (base-10 logarithms) to reduce heteroscedasticity and skewness of the residuals and meet SLR model assumptions (Helsel and Hirsch, 2002). PD provides a measure of the difference between two values when one value is assumed to be more representative of the true value. RPD provides a measure of the relative difference between two values when neither of the two values is representative of the true value.

Datasets were examined for outliers before doing statistical analyses. Outliers (table 3 ) were identified by a low percentage of fine particle sizes (less than $0.0625 \mathrm{~mm}$ ) relative to other samples. Two outliers (table 3 ) were identified and removed from the dataset before doing analyses. Outliers can result from errors during data collection. Examples of data collection errors include the sampler not being raised from the streambed fast enough, which could have disrupted the streambed and contaminated the sample, or the sampler could have accidently come into contact with a sand dune and also contaminated the sample. Also, outliers could result from natural anomalies that deviate from the rest of the dataset.

\section{Field Sampling and Laboratory Analysis Method Comparison}

The study design allowed five sets of comparisons between field sampling and laboratory analysis method combinations. The comparison of EWDI-SSC to Grab-TSS represents the USGS and MPCA field sampling and laboratory analysis methods, respectively. This comparison has been described by Gray and others (2000) and Ellison and others (2014). The two field sampling method comparisons were EWDI-SSC to Grab-SSC and EWDI-TSS to Grab-TSS. The two comparisons for laboratory analysis methods were GrabSSC to Grab-TSS and EWDI-SSC to EWDI-TSS. The data used for the comparisons are listed in table 2. Visualizations of the field sampling and laboratory analysis method comparisons used in the following sections are shown in figure 3.
Mean and median values of EWDI-SSC were (fig. 4) greater than Grab-SSC, EWDI-TSS, and Grab-TSS (table 4). Also, Grab-SSC had greater mean and median values than the EWDI-TSS and Grab-TSS (table 4). Boxplots (fig. 4) showed minimal differences between methods; however, closer inspection of the differences among paired samples indicated that the differences were statistically significant.

The Wilcoxon signed-rank test was used to test if differences between concurrent pairs of samples from grab and EWDI field sampling methods and laboratory analysis methods of TSS and SSC median values were statistically significant. Overall, the comparison of EWDI-SSC samples to Grab-TSS samples was statistically significant (probability value $[p$-value] less than 0.01 ; table 5$)$. The PD in this comparison was 41 percent with the EWDI-SSC median value being greater than the Grab-TSS median value (table 5). For the two field sampling method comparisons (EWDI compared to grab), results indicated that median concentrations for EWDI samples (EWDI-SSC and EWDI-TSS) were statistically significant ( $p$-value less than 0.01 ) being greater than the corresponding median concentrations for grab samples (Grab-SSC and Grab-TSS), respectively. The PDs between the two field sampling methods were 27 and 13 percent for EWDI-SSC to Grab-SSC and EWDI-TSS to Grab-TSS, respectively (table 5). The analysis of the two laboratory analysis method comparisons indicated that the median concentrations were statistically significant ( $p$-value less than $0.01)$ for SSC and TSS. The SSC laboratory analysis method yielded substantially larger median concentrations than the TSS laboratory analysis method. The PDs for the two laboratory analysis methods were 32 and 19 percent for the EWDISSC to EWDI-TSS and Grab-SSC to Grab-TSS comparisons, respectively (table 5).

Scatterplots and SLR best-fit lines are presented to demonstrate the relations between each field sampling and laboratory analysis method combination. The 1:1 and SLR best-fit lines were plotted for each comparison. The 1:1 line indicates agreement between the two concentration datasets being plotted, and the SLR best-fit line indicates the estimated relation between the two datasets being compared. If the data and SLR best-fit line plots are above the 1:1 line, the response variable (y-axis; fig. 5) is larger than the explanatory variable (x-axis; fig. 5). Conversely, if the explanatory variable is larger than the response variable, then the data and SLR best-fit line plots are below the 1:1 line.

Patterns among the field sampling and laboratory analysis methods are indicated on figure 5. All the combinations had strong and significant relations with coefficients of determination $\left(R^{2}\right)$ greater than or equal to 0.94 and $p$-values less than 0.01 (table 6). Even though the grouped data have strong and significant relations, a site-specific relation between SSC and TSS should be the primary method to estimate SSC from TSS (Glysson and others, 2000). The SLR analysis indicated when 


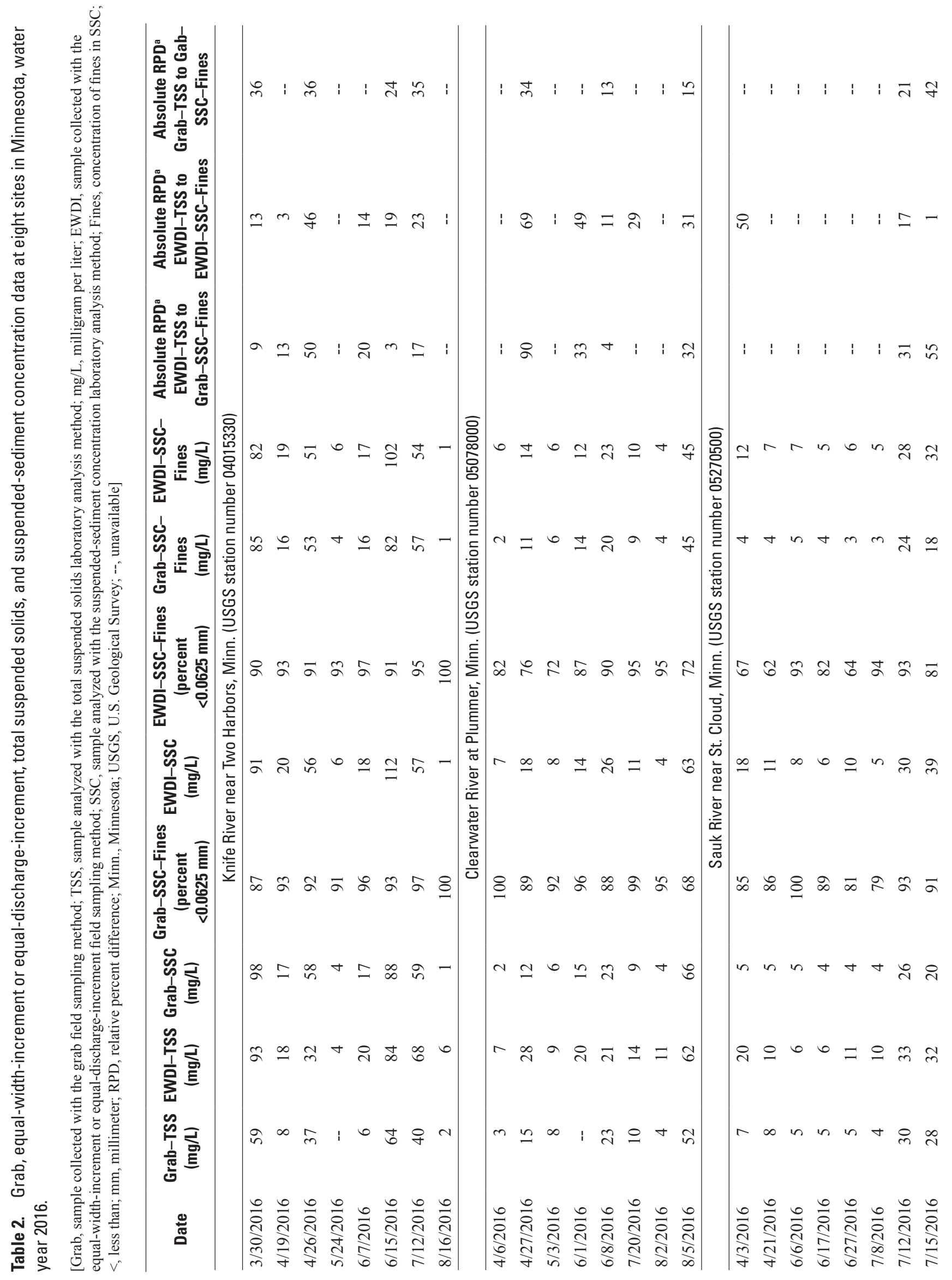




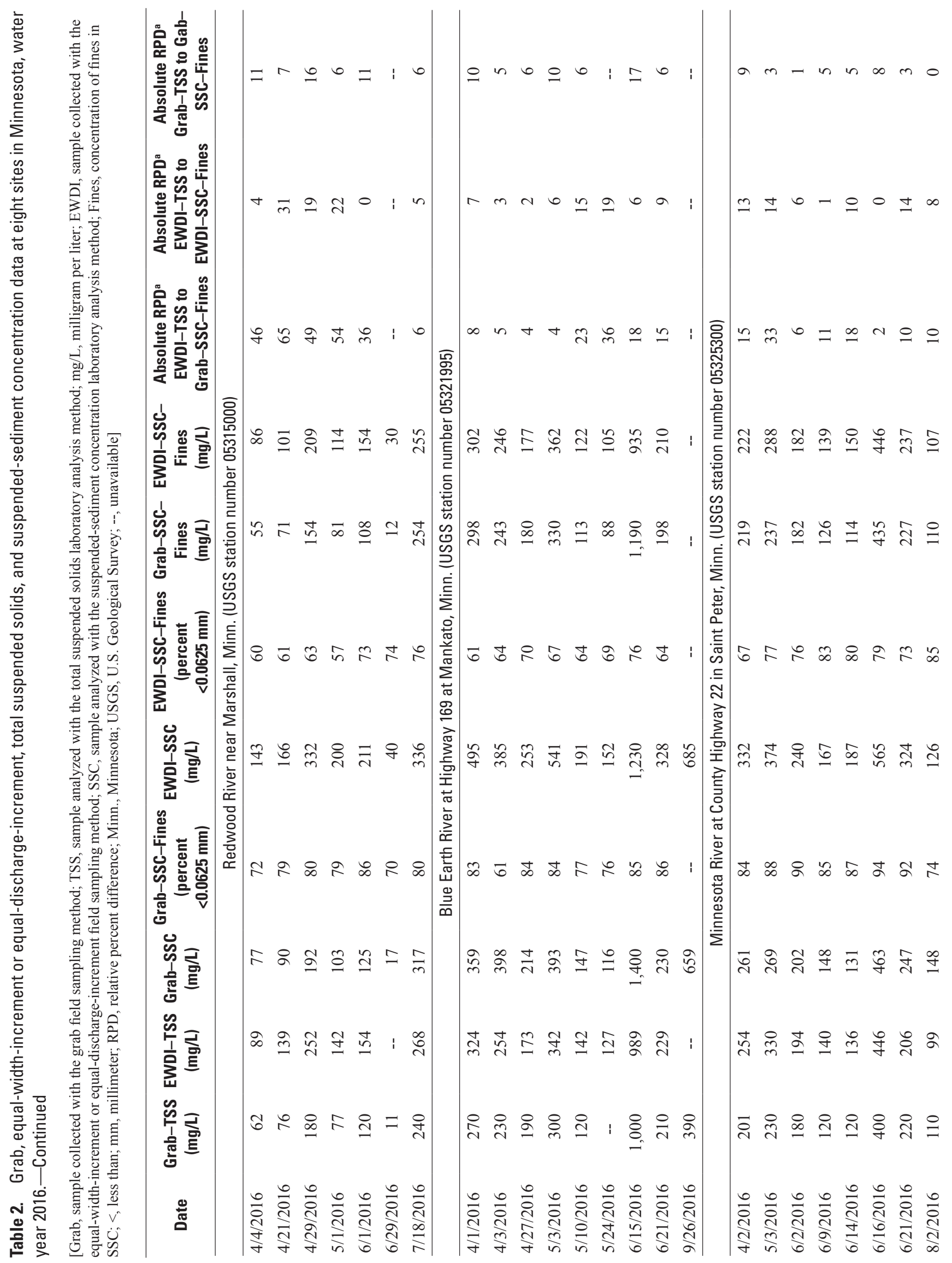




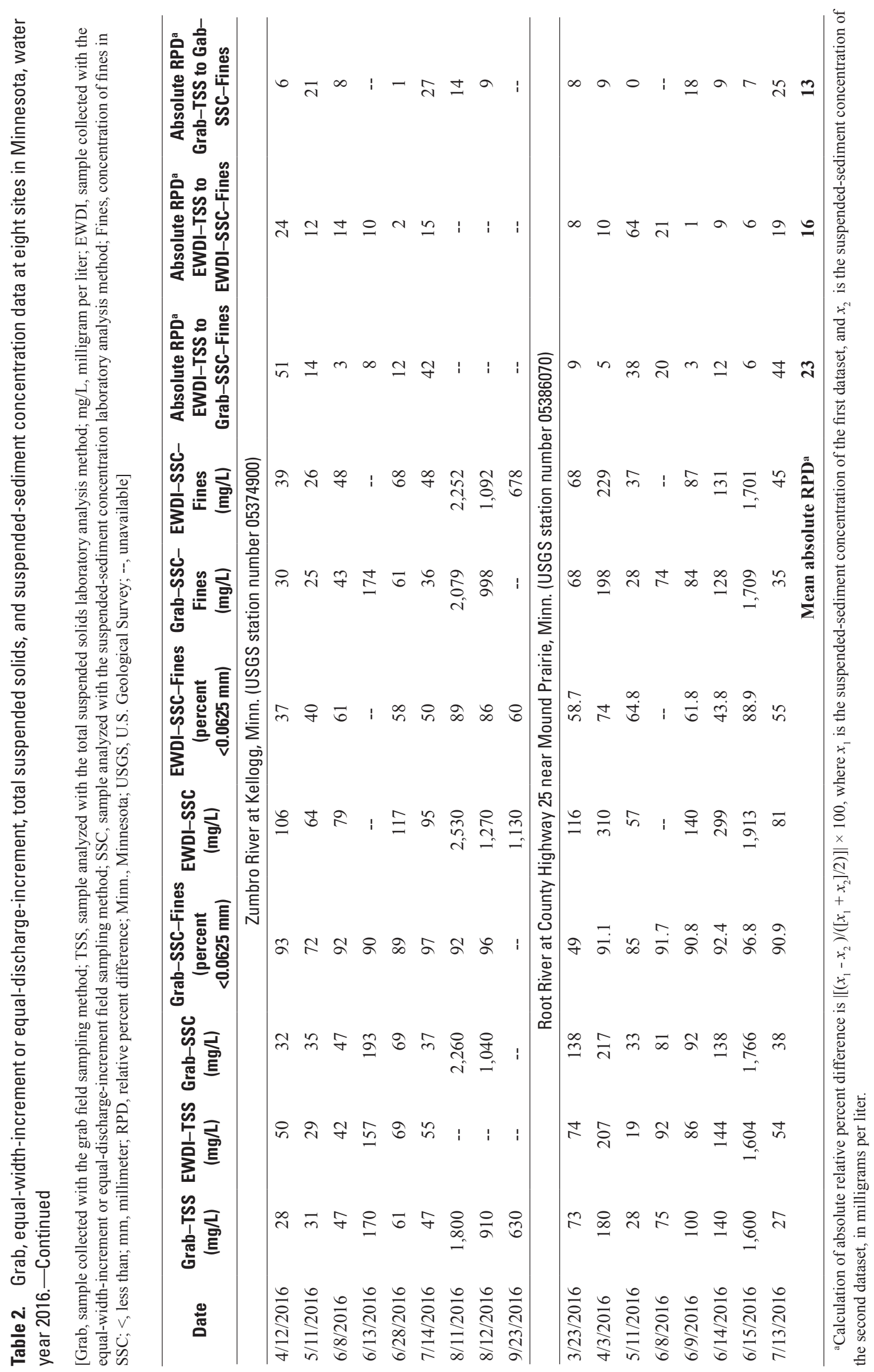


Table 3. Suspended-sediment concentration outliers, water year 2016.

[USGS, U.S. Geological Survey; EWDI, sample collected with the equal-width-increment or equal-discharge-increment field sampling method; suspended-sediment concentration; SSC, sample analyzed with the suspended-sediment concentration laboratory analysis method; mg/L, milligram per liter; <, less than; mm, millimeters; Minn., Minnesota]

\begin{tabular}{|c|c|c|c|c|c|}
\hline Station name & $\begin{array}{c}\text { USGS } \\
\text { station number }\end{array}$ & Date & Time & $\begin{array}{c}\text { EWDI-SSC } \\
(\mathrm{mg} / \mathrm{L})\end{array}$ & $\begin{array}{c}\text { EWDI-SSC Fines } \\
\text { (percent }<0.0625 \mathrm{~mm} \text { ) }\end{array}$ \\
\hline $\begin{array}{l}\text { Root River at County Highway } 25 \text { near } \\
\text { Mound Prairie, Minn. }\end{array}$ & 05386070 & $6 / 8 / 2016$ & $17: 50$ & 780 & 10.9 \\
\hline Zumbro River at Kellogg, Minn. & 05374900 & 6/13/2016 & $15: 25$ & 633 & 30 \\
\hline
\end{tabular}

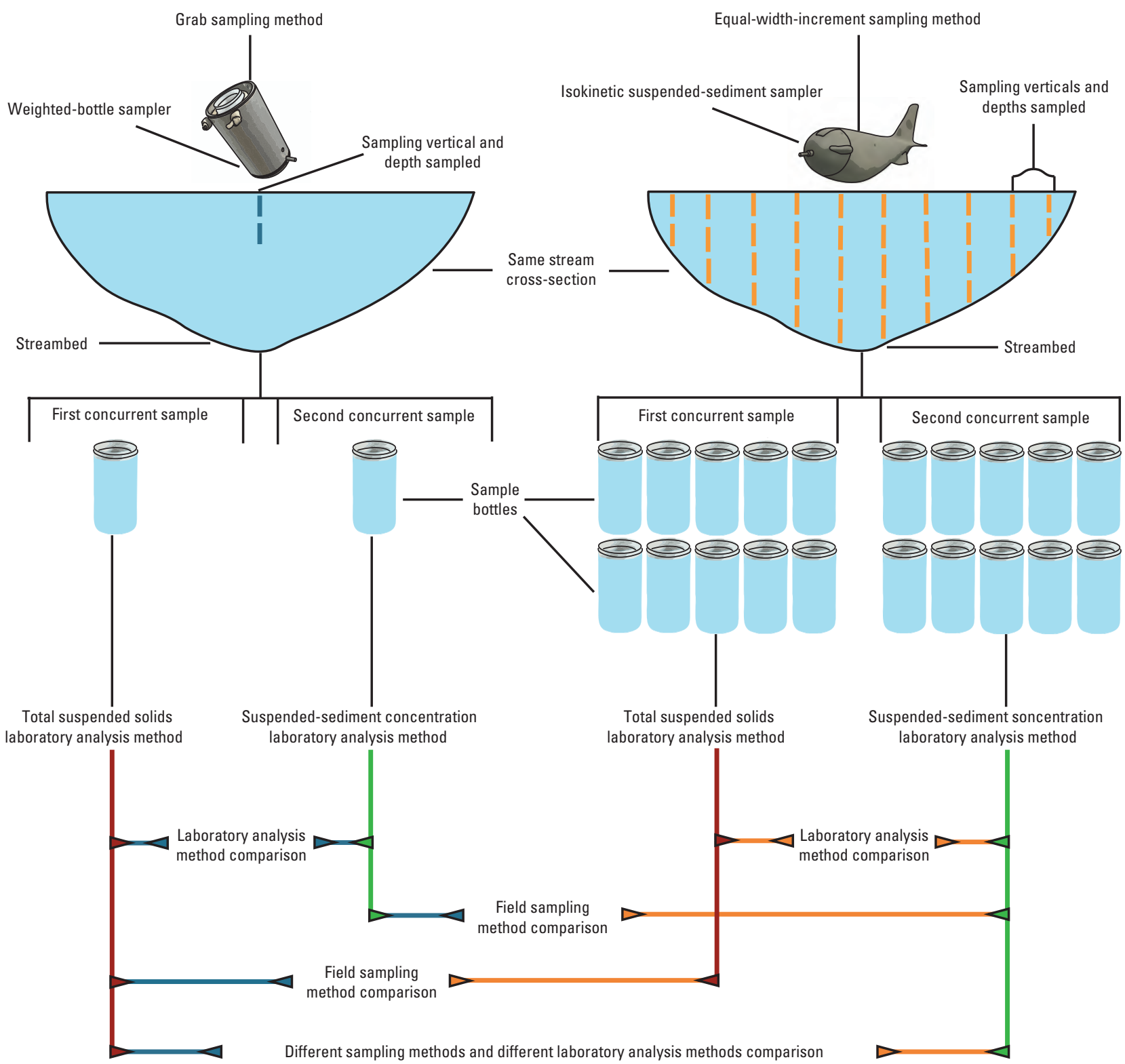

EXPLANATION

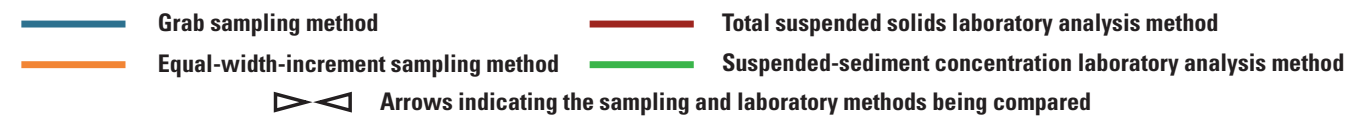

Figure 3. Infographic demonstrating five combinations of field sampling and laboratory analysis methods used to compare differences in sediment concentrations. 
Different field sampling and laboratory analysis methods

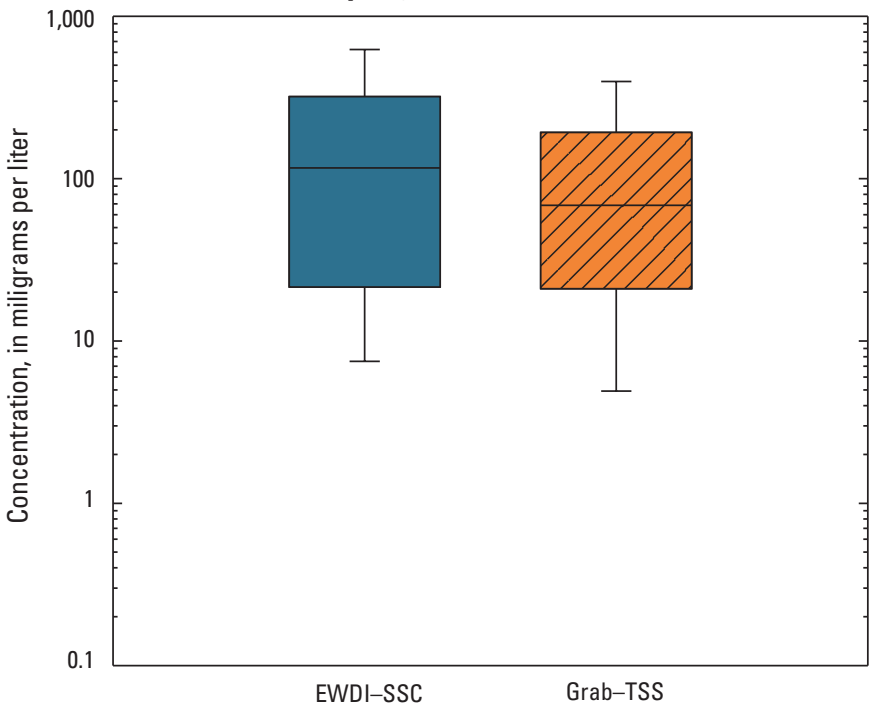

Laboratory analysis methods

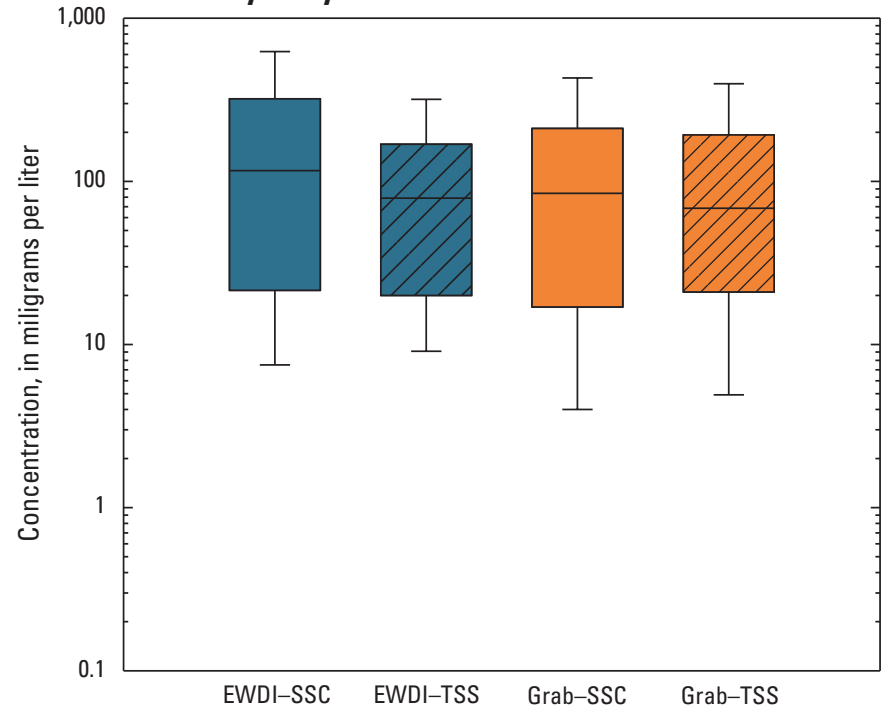

Field sampling methods

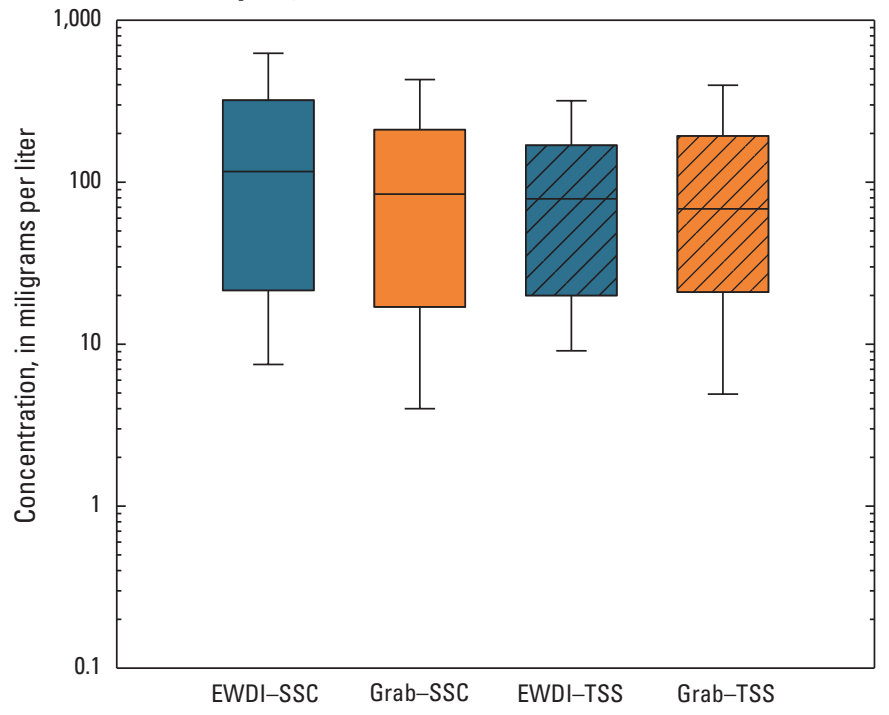

\section{EXPLANATION}
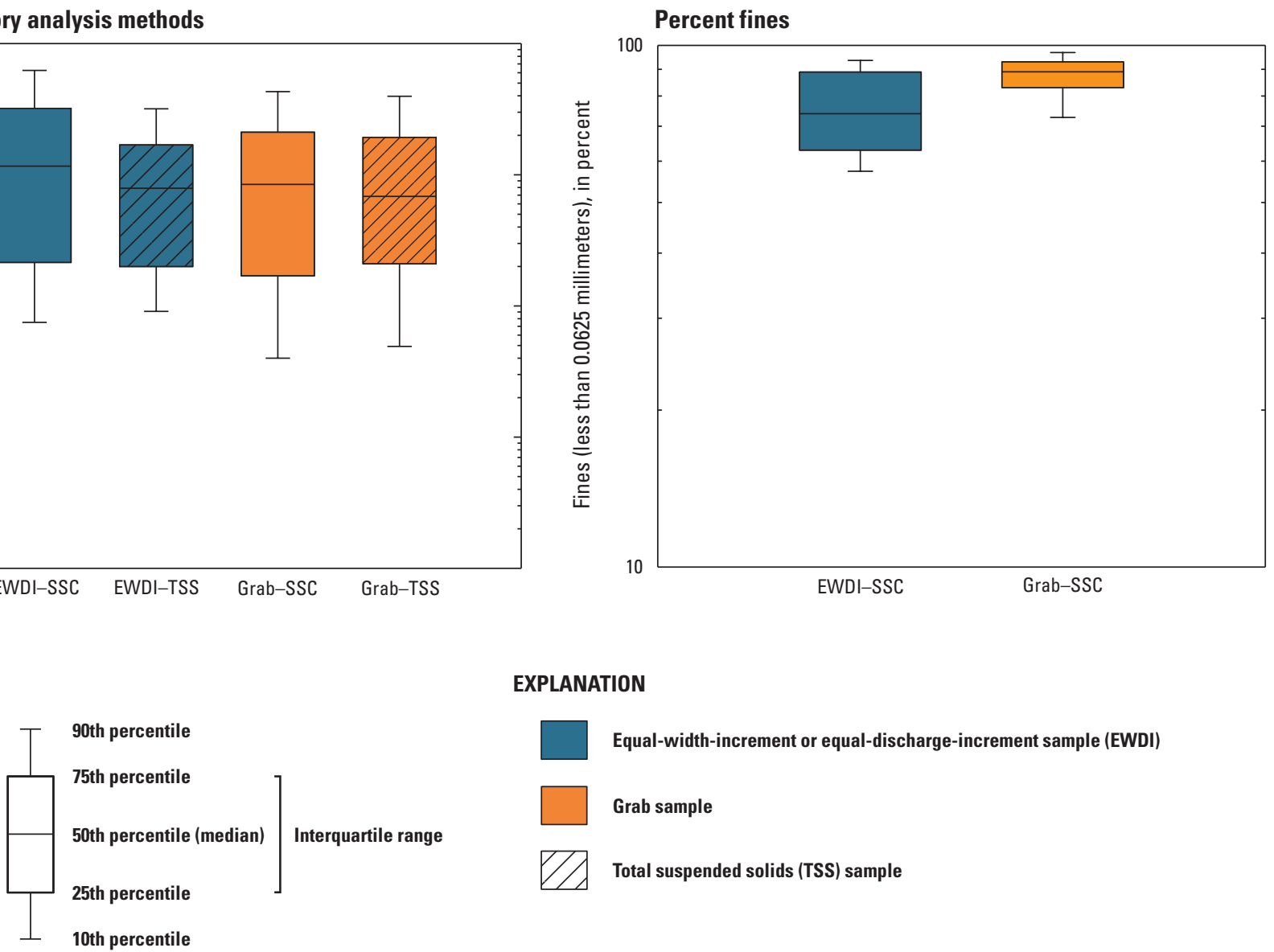

Figure 4. Box plots for grab samples, equal-width-increment or equal-discharge-increment samples, total suspended solids, suspended-sediment concentrations (SSC), and percent fines data at eight sites in Minnesota, water year 2016. 
Table 4. Summary statistics for grab sampling, equal-width-increment or equal-discharge-increment sampling, total suspended solids, suspended-sediment concentrations, and percent fines at eight sites in Minnesota, water year 2016.

[ $n$, number of samples; Grab, sample collected with the grab field sampling method; TSS, sample analyzed with the total suspended solids laboratory analysis method; $\mathrm{mg} / \mathrm{L}$, milligram per liter; EWDI, sample collected with the equal-width-increment or equaldischarge-increment field sampling method; SSC, sample analyzed with the suspended-sediment concentration laboratory analysis method; Fines, concentration of fines in SSC; <, less than; mm, millimeter]

\begin{tabular}{lrrrrrr}
\hline \multicolumn{1}{c}{ Method combination } & Minimum & Mean & Median & Maximum & Total $\boldsymbol{n}$ & $\begin{array}{c}\text { Standard } \\
\text { deviation }\end{array}$ \\
\hline Grab-TSS (mg/L) & 2 & 184 & 69 & 1,800 & 62 & 339 \\
EWDI-TSS (mg/L) & 4 & 146 & 79 & 1,604 & 60 & 245 \\
Grab-SSC (mg/L) & 1 & 211 & 85 & 2,260 & 64 & 405 \\
Grab-SSC-Fines (percent $<0.0625 \mathrm{~mm})$ & 49 & 87 & 89 & 100 & 63 & 10 \\
EWDI-SSC (mg/L) & 1 & 269 & 116 & 2,530 & 63 & 454 \\
EWDI-SSC-Fines (percent $<0.0625 \mathrm{~mm})$ & 37 & 74 & 74 & 100 & 62 & 15 \\
\hline
\end{tabular}

Table 5. Summary of Wilcoxon signed-rank tests used to evaluate differences between field sampling and laboratory analysis method combinations in Minnesota, water year 2016.

[Grab, sample collected with the grab field sampling method; TSS, sample analyzed with the total suspended solids laboratory analysis method; $\mathrm{mg} / \mathrm{L}$, milligram per liter; SSC, sample analyzed with the suspendedsediment concentration laboratory analysis method; EWDI, sample collected with the equal-width-increment or equal-discharge-increment field sampling method; PD, percent difference; $\mathrm{V}$, sum of ranks assigned to the differences with a positive sign; $p$-value, probability value; $<$, less than]

\begin{tabular}{cccc}
\hline Grab-TSS (mg/L) & Grab-SSC (mg/L) & $\begin{array}{c}\text { EWDI-TSS } \\
(\mathbf{m g} / \mathbf{L})\end{array}$ & $\begin{array}{c}\text { EWDI-SSC } \\
(\mathbf{m g} / \mathbf{L})\end{array}$ \\
\hline & Median & & \\
\hline 69 & 85 & 79 & 116 \\
\hline $\begin{array}{c}\text { Method combination comparison } \\
\left(\boldsymbol{x}_{\mathbf{1}} \text { to } \boldsymbol{x}_{\mathbf{2}}{ }^{\text {}}\right)\end{array}$ & $\mathbf{P D}^{\text {a }}$ & $\mathbf{V}$ & $\boldsymbol{p}$-value \\
\hline EWDI-SSC to Grab-TSS & 41 & 7 & $<0.01$ \\
Grab-SSC to Grab-TSS & 19 & 158 & $<0.01$ \\
EWDI-SSC to EWDI-TSS & 32 & 151 & $<0.01$ \\
EWDI-TSS to Grab-TSS & 13 & 242 & $<0.01$ \\
EWDI-SSC to Grab-SSC & 27 & 176 & $<0.01$ \\
\hline
\end{tabular}

${ }^{a}$ Calculation of percent difference is $\left[\left(x_{1}-x_{2}\right) / x_{1}\right] \times 100$, where $x_{1}$ is the median concentration of the first dataset, and $x_{2}$ is the median concentration of the second dataset, in milligrams per liter.

the field sampling and laboratory analysis methods were different, the data plotted farthest above the 1:1 line than all the other comparisons (fig. 5A), indicating Grab-TSS consistently underpredicts EWDI-SSC.

For field sampling comparisons (figs. $5 B, 5 C$ ), EWDI samples are assumed to be the most representative of sediment concentration in the river. When SLR best-fit lines are above the 1:1 line, this indicates that concentrations derived from grab samples underrepresent the sediment concentration (negative bias). For sediment concentrations less than $200 \mathrm{mg} / \mathrm{L}$, concentrations derived from grab samples were negatively biased. As sediment concentrations approach $200 \mathrm{mg} / \mathrm{L}$, this negative bias associated with grab samples decreases. This decrease in negative bias likely is the result of higher water velocities mixing suspended sediment homogenously throughout the stream channel. For SSC analyses, concentrations in grab samples were never positively biased throughout the measured range of sediment concentrations (fig. 5C). Conversely, for TSS analyses, concentrations derived from grab samples approached the 1:1 line when sediment concentrations approached $200 \mathrm{mg} / \mathrm{L}$ (fig. 5B). 

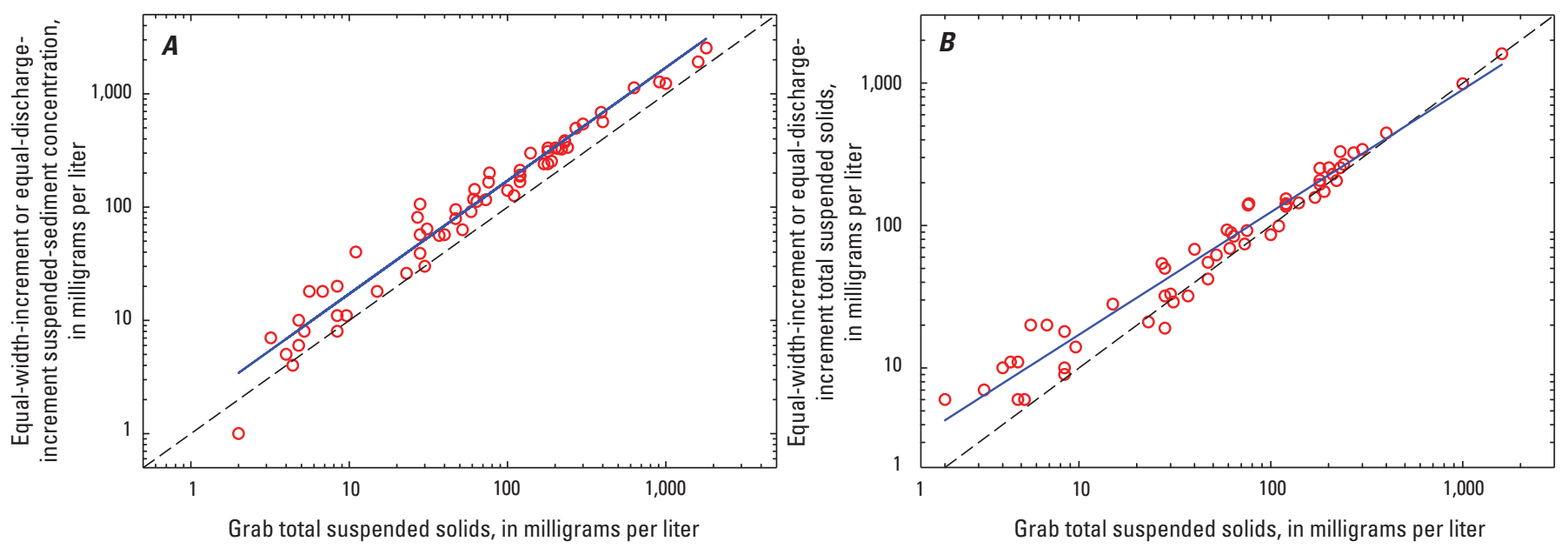

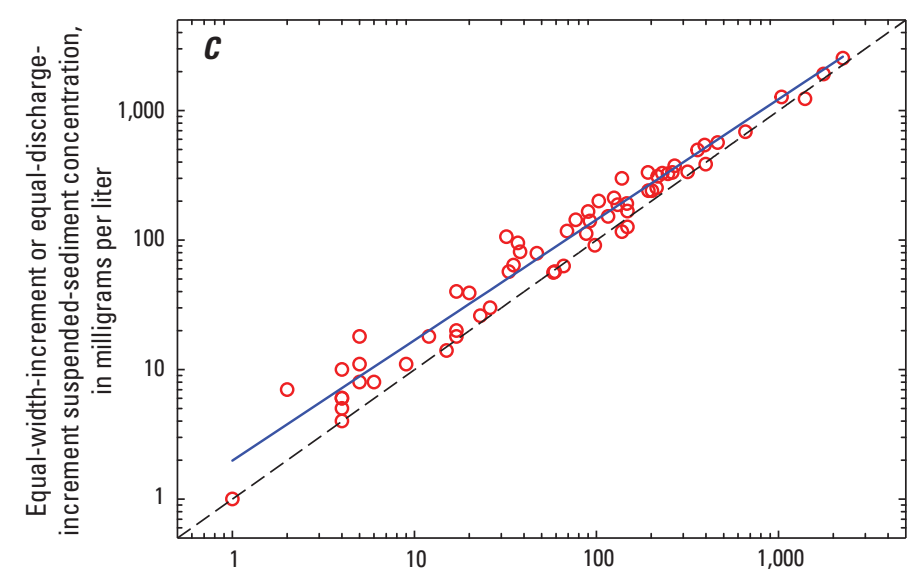

Grab suspended-sediment concentration, in milligrams per liter

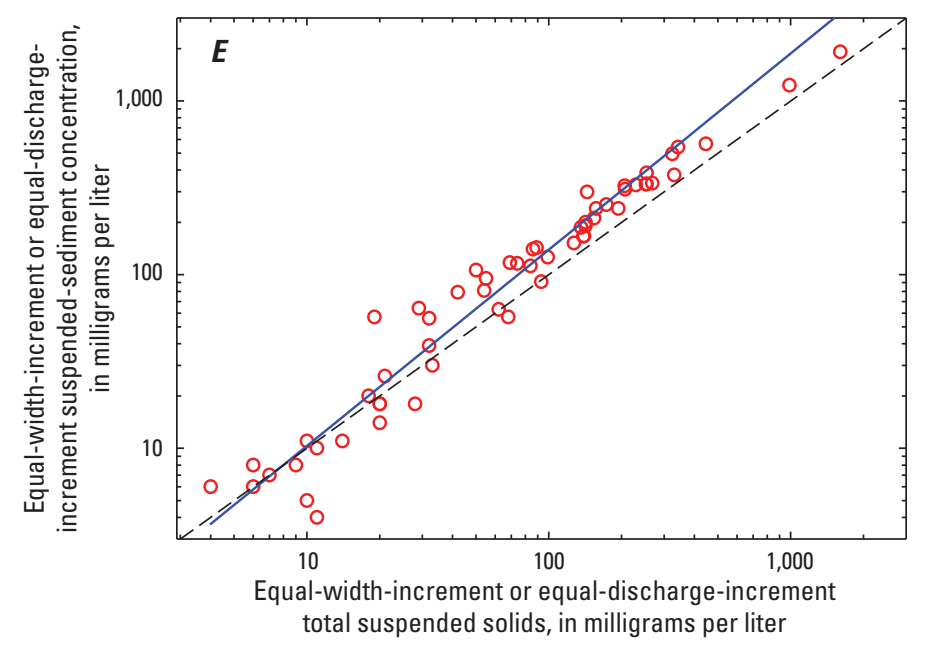

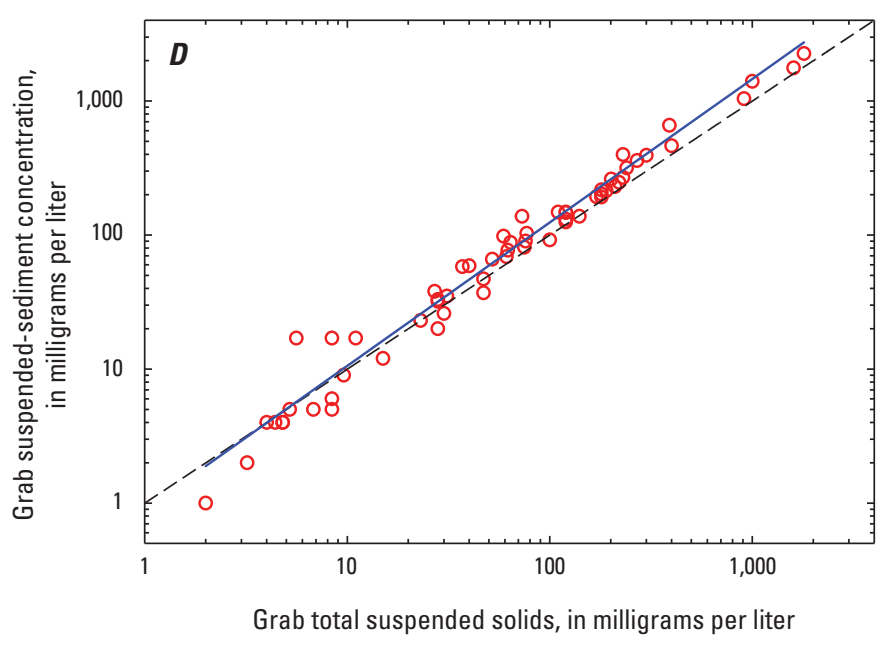

EXPLANATION

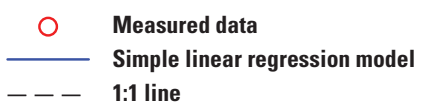

Figure 5. Relations between $A$, different field sampling and laboratory analysis methods, $B$ and $C$, field sampling methods, and $D$ and $E$, laboratory analysis methods in Minnesota, water year 2016. 
Table 6. Summary of simple linear regression models to evaluate field sampling and laboratory analysis method combinations in Minnesota, water year 2016.

[ $n$, number of samples; $R^{2}$, coefficient of determination; $p$-value, probability value; $\mathrm{BCF}$, bias correction factor; EWDI, sample collected with the equal-widthincrement or equal-discharge-increment field sampling method; SSC, sample analyzed with the suspended-sediment concentration laboratory analysis method; Grab, sample collected with the grab field sampling method; TSS, sample analyzed with the total suspended solids laboratory analysis method; <, less than]

\begin{tabular}{|c|c|c|c|c|c|c|c|}
\hline $\begin{array}{c}\text { Method combination } \\
\text { comparison }\end{array}$ & $n$ & Simple linear regression model & $\begin{array}{l}\text { Standard } \\
\text { error }\end{array}$ & $R^{2}$ & $\begin{array}{l}\text { Average model } \\
\text { standard } \\
\text { percentage error }\end{array}$ & $p$-value & $\mathrm{BCF}^{\mathrm{a}}$ \\
\hline EWDI-SSC to Grab-TSS & 61 & $E W D I-S S C=1.622 \times G r a b-T S S^{0.999 b}$ & 0.149 & 0.96 & 35 & $<0.01$ & 1.06 \\
\hline Grab-SSC to Grab-TSS & 61 & $G r a b-S S C=0.857 \times G r a b-T S S^{1.07 b}$ & 0.123 & 0.97 & 28.7 & $<0.01$ & 1.05 \\
\hline EWDI-SSC to EWDI-TSS & 59 & $E W D I-S S C=0.714 \times E W D I-T S S^{1.13 b}$ & 0.175 & 0.94 & 41.3 & $<0.01$ & 1.07 \\
\hline EWDI-TSS to Grab-TSS & 57 & $E W D I-T S S=2.275 \times G r a b-T S S^{0.86 b}$ & 0.125 & 0.95 & 29.2 & $<0.01$ & 1.04 \\
\hline EWDI-SSC to Grab-SSC & 63 & $E W D I-S S C=1.888 \times G r a b-S S C^{0.93 b}$ & 0.139 & 0.96 & 32.6 & $<0.01$ & 1.05 \\
\hline
\end{tabular}

aBias correction factor or "smearing" estimator is used to correct retransformation bias of regression estimates (Duan, 1983).

${ }^{\mathrm{b} S l o p e}$ coefficent.

For laboratory comparisons (figs. $5 D, 5 E$ ), the SSC samples are assumed to be the most representative sediment concentration. SSC analyses indicated a slight positive bias at sediment concentrations less than $40 \mathrm{mg} / \mathrm{L}$ (figs. $5 D, 5 E$ ). At sediment concentrations greater than $40 \mathrm{mg} / \mathrm{L}$, TSS concentrations were negatively biased (figs. $5 D, 5 E$ ). These comparisons followed observations by Gray and others (2000) and indicated the TSS laboratory analysis methods were most likely biased because of sand-sized particles (greater than or equal to $0.0625 \mathrm{~mm}$ ) because the SSC method measures the sediment mass, whereas the TSS method was unable to capture a representative subsample because of sand settling during the extraction procedure.

\section{Effect of Particle Size on Sampling and Laboratory Analysis Methods}

The median values (table 4) and boxplots (fig. 4) indicated that samples collected using the Grab-SSC method had a greater percentage of fines than samples collected using the EWDI-SSC method. The grab field sampling method may not capture sand contributions to SSCs, resulting in artificially greater percentages of fines compared to EWDI-SSC samples (Gray and others, 2000; Ellison and others, 2014). Stream velocity can affect the occurrence and distribution of sand-sized particles near the streambed or in other sections of the stream cross section. A grab sample only incorporates water from a single location near the water surface (less than 1 meter), and most paired sampling were during stream conditions where water depths exceeded 1 meter. Whereas, samples collected using the EWDI method integrate the vertical water column and exclude the lowest 10 centimeters above the streambed; furthermore, samples collected using the EWDI method incorporate water from 5 to 10 locations across the horizontal stream cross section.
Gray and others (2000) stated that the difference between SSC and TSS was intensified when the contribution of sandsize particles was greater than or equal to 25 percent. For this study, the median of all the percentages of the sand in the EWDI-SSC was 26 percent and was selected as a threshold value to produce two groups of data for the dataset. One group consisted of values greater than or equal to 26 percent sands and one group less than 26 percent sands. This value of 26 percent was selected because it was close to the findings of Gray and others (2000) that indicated the differences between SSC and TSS laboratory results were exacerbated when the contribution of sand-size particles was greater than or equal to 25 percent. For the subsequent analysis investigating the effects of percentages of sand-sized particles on field sampling and laboratory analysis methods, EWDI-SSC, Grab-TSS, Grab-SSC, and EWDI-TSS paired values that had greater than 26 percent sand in the EWDI-SSC will hereafter be referred to as "sands," and values less than or equal to 26 percent sand in the EWDI-SSC will hereafter be referred to as "fines."

After the dataset was divided into sands and fines, SLR analyses were done on the fines and sands datasets. All the comparisons had strong and significant relations $\left(R^{2}\right.$ values were greater than or equal to 0.92 , and $p$-values were less than 0.01; table 7). The slope coefficients of the SLR models ranged from 0.84 to 1.12 (table 7). The sands plotted farthest above the 1:1 line in the comparison of EWDI-SSC to GrabTSS (fig. 6A). Error was cumulative as sand increased because the grab method failed to capture sand in the sample, whereas the TSS laboratory analysis method failed to capture sand during the extraction procedure.

When comparing field sampling methods, EWDI samples are assumed to be most representative of the true sediment concentration. For the two different field sampling methods (EWDI compared to grab), samples with greater percentages of sand-size particles provided a marked separation in sands 
Table 7. Summary of simple linear regression models to evaluate effect of sand-sized particles on field sampling and laboratory analysis method combinations in Minnesota, water year 2016.

$\left[\geq\right.$, greater than or equal to; $\mathrm{mm}$, millimeter; $n$, number of samples; $R^{2}$, coefficient of determination; $p$-value, probability value; $\mathrm{BCF}$, bias correction factor; EWDI, sample collected with the equal-width-increment or equal-discharge-increment field sampling method; SSC, sample analyzed with the suspendedsediment concentration laboratory analysis method; Grab, sample collected with the grab field sampling method; TSS, sample analyzed with the total suspended solids laboratory analysis method; $<$, less than]

\begin{tabular}{|c|c|c|c|c|c|c|c|}
\hline \multirow[b]{2}{*}{$\begin{array}{l}\text { Method combination } \\
\text { comparison }\end{array}$} & \multicolumn{7}{|c|}{ Sands $(\geq 0.0625 \mathrm{~mm})$} \\
\hline & $n$ & Simple linear regression model & $\begin{array}{l}\text { Standard } \\
\text { error }\end{array}$ & $R^{2}$ & $\begin{array}{l}\text { Average model } \\
\text { standard } \\
\text { percentage error }\end{array}$ & $p$-value & $\mathrm{BCF}^{\mathrm{a}}$ \\
\hline EWDI-SSC to Grab-TSS & 31 & $E W D I-S S C=2.388 \times G r a b-T S S^{0.942 b}$ & 0.128 & 0.94 & 29.9 & $<0.01$ & 1.04 \\
\hline Grab-SSC to Grab-TSS & 30 & $G r a b-S S C=0.724 \times G r a b-T S S^{1.11 b}$ & 0.096 & 0.97 & 22.4 & $<0.01$ & 1.02 \\
\hline EWDI-SSC to EWDI-TSS & 30 & $E W D I-S S C=1.203 \times E W D I-T S S^{1.04 \mathrm{~b}}$ & 0.118 & 0.94 & 27.6 & $<0.01$ & 1.04 \\
\hline EWDI-TSS to Grab-TSS & 29 & $E W D I-T S S=1.995 \times G r a b-T S S^{0.887 b}$ & 0.128 & 0.92 & 30 & $<0.01$ & 1.04 \\
\hline EWDI-SSC to Grab-SSC & 31 & $E W D I-S S C=3.289 \times G r a b-S S C^{0.84 b}$ & 0.116 & 0.94 & 27.1 & $<0.01$ & 1.03 \\
\hline \multirow[b]{2}{*}{$\begin{array}{l}\text { Method combination } \\
\text { comparison }\end{array}$} & \multicolumn{7}{|c|}{ Fines $(<0.0625 \mathrm{~mm})$} \\
\hline & $n$ & Simple linear regression model & $\begin{array}{l}\text { Standard } \\
\text { error }\end{array}$ & $R^{2}$ & $\begin{array}{l}\text { Average model } \\
\text { standard percent- } \\
\text { age error }\end{array}$ & $p$-value & BCF $^{a}$ \\
\hline EWDI-SSC to Grab-TSS & 30 & $E W D I-S S C=1.324 \times G r a b-T S S^{1.01 b}$ & 0.14 & 0.978 & 32.7 & $<0.01$ & 1.05 \\
\hline Grab-SSC to Grab-TSS & 31 & $E W D I-S S C=0.914 \times G r a b-T S S^{1.06 b}$ & 0.145 & 0.97 & 34.1 & $<0.01$ & 1.06 \\
\hline EWDI-SSC to EWDI-TSS & 29 & $E W D I-S S C=0.608 \times E W D I-T S S^{1.12 b}$ & 0.194 & 0.94 & 46.1 & $<0.01$ & 1.08 \\
\hline EWDI-TSS to Grab-TSS & 28 & $E W D I-T S S=2.393 \times G r a b-T S S^{0.852 b}$ & 0.125 & 0.96 & 29.2 & $<0.01$ & 1.04 \\
\hline EWDI-SSC to Grab-SSC & 32 & $E W D I-S S C=1.469 \times G r a b-S S C^{0.951 b}$ & 0.11 & 0.98 & 25.6 & $<0.01$ & 1.03 \\
\hline
\end{tabular}

aias correction factor or "smearing" estimator is used to correct retransformation bias of regression estimates (Duan, 1983).

${ }^{\mathrm{b} S}$ lope coefficent.

and fines SLR best-fit lines (figs. 6C). The comparisons of EWDI-SSC to Grab-SSC (fig. 6C) provided further evidence that grab samples underrepresent sediment concentrations. The fines best-fit line followed a similar pattern, but the grab samples only slightly underrepresented the sediment concentration (fig. $6 \mathrm{C}$ ). When comparing EWDI-TSS to Grab-TSS, the small separation between the sands and fines SLR best-fit lines indicated that sand-size particles had less of an effect when the TSS laboratory analysis method was used to determine concentrations (fig. $6 B$ ). A possible explanation for the small separation between sand and fines SLR best-fit lines in figure $6 B$ was that the TSS laboratory analysis method likely was masking the effect of sand-sized particles.

When comparing laboratory analysis methods, SSC samples are assumed to provide the most representative sediment concentration. Sands had a greater effect on the EWDI-SSC to EWDI-TSS comparison (fig. 6E) than on the Grab-SSC to GrabTSS comparison (fig. 6D). For EWDI-SSC to EWDI-TSS, the EWDI-TSS sand samples underestimated the most representative sediment concentration throughout the range of samples (fig. $6 E$ ). For Grab-SSC to Grab-TSS, the sands followed almost an identical pattern as the fines and had little effect (fig. $6 D$ ).
By comparing the concentration of fines from the SSC analysis to the TSS analysis and seeing how closely they match, understanding can be gained to determine if sand is being captured through TSS analysis. The concentration of fines in SSC was calculated from equation 1:

$$
\text { Concentration of Fines }=\left(\left[\frac{P F}{100}\right] \times S S C\right)
$$

where

$$
\begin{gathered}
\text { PF is the percentage of fines less than } \\
0.0625 \text { millimeters; and } \\
\text { SSC is the suspended-sediment concentration, in } \\
\text { milligrams per liter. }
\end{gathered}
$$

All values of $10 \mathrm{mg} / \mathrm{L}$ or less were not considered in these comparisons because of the high variance with laboratory analysis at low concentrations. The concentrations of fines will be combined to the field sampling and laboratory analysis method abbreviations in the following section of the report; for example, the concentration of fines will be referred to as, "Fines" and will follow an en dash (-) after the laboratory method abbreviation (TSS or SSC). 

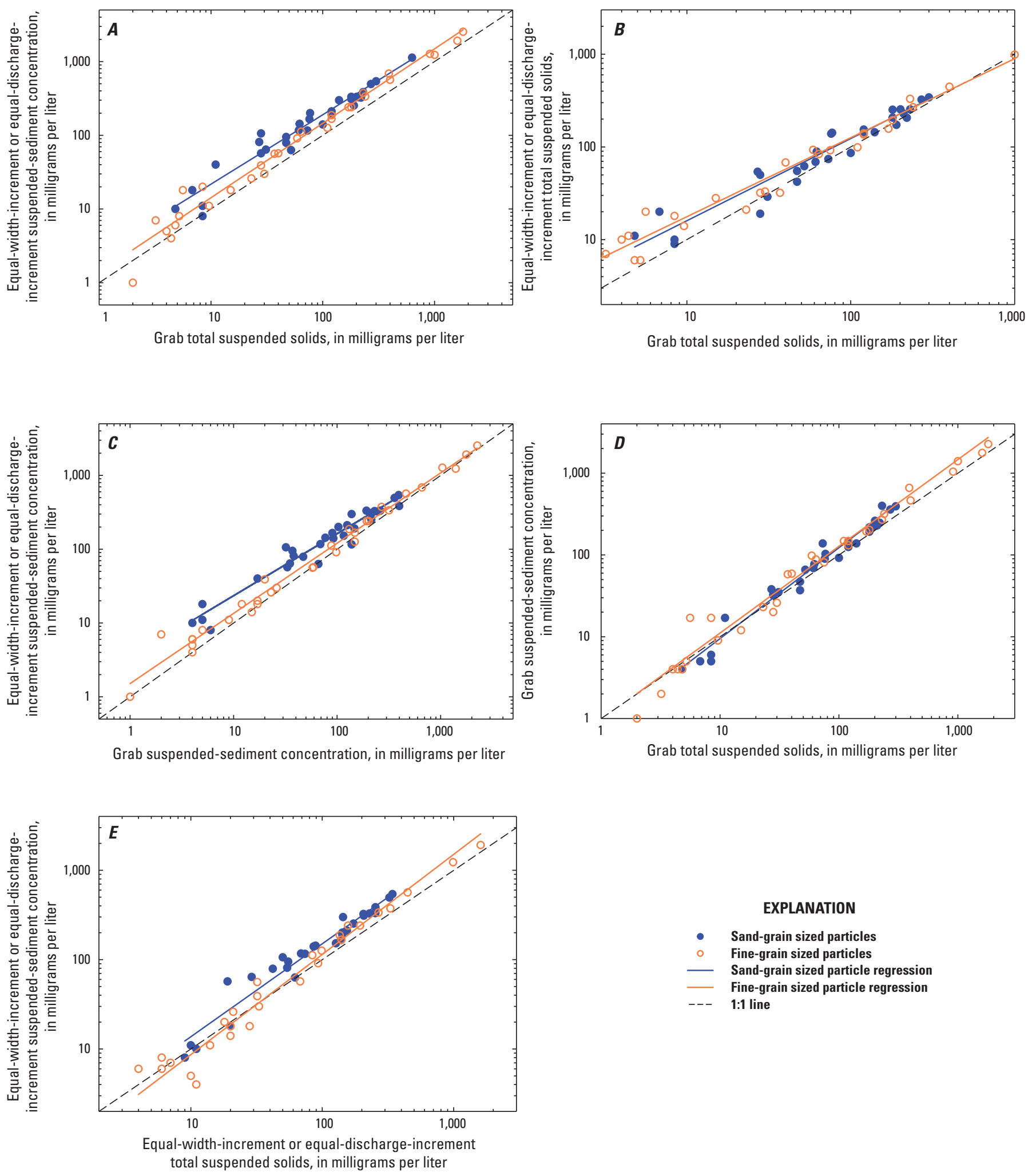

\section{EXPLANATION}

- Sand-grain sized particles Fine-grain sized particles Sand-grain sized particle regression Fine-grain sized particle regression --- $\quad$ 1:1 line

Figure 6. Sand-sized particles effect on relations between $A$, different field sampling and laboratory analysis methods, $B$ and $C$, field sampling methods, and $D$ and $E$, laboratory analysis methods in Minnesota, water year 2016. 
Mean absolute RPDs between SSC-Fines and TSS demonstrated the substantial effect of sand on sediment concentrations (table 2). When comparing field sampling methods and laboratory analysis methods, the difference between concentrations for EWDI-TSS and Grab-SSC-Fines had a mean absolute RPD of 23 percent. When comparing laboratory analysis methods, the mean absolute RPD decreased to 16 percent when comparing EWDI-TSS and EWDI-SSC-Fines. The mean absolute RPD was 13 percent when comparing the Grab-TSS and Grab-SSC-Fines. When comparing Grab-TSS and Grab-SSC-Fines, the mean absolute RPD was the lowest indicating less sand-size particles were being captured using the grab field sampling and TSS laboratory analysis methods.

\section{Quality Assurance}

Quality-assurance replicate samples were collected to assess the variation in the reproducibility of field sampling and laboratory analysis methods (table 8). Concurrent replicate samples were collected with the EWDI field sampling method most of the time and analyzed for SSC at Knife River near Two Harbors, Minn. (USGS station 04015330), Blue Earth River at Highway 169 at Mankato, Minn. (USGS station 05321995), Minnesota River at County Highway 22 in Saint
Peter, Minn. (USGS station 05325300), and Zumbro River at Kellogg, Minn. (USGS station 05374900). Overall, the mean absolute RPD of 6 percent was small, indicating that field sampling and laboratory analysis methods primarily used by the USGS are reproducible and consistent.

An exploratory comparison of the TSS analyses completed by the two different laboratories (USGS Sediment Laboratory and MDH Environmental Laboratory) was completed to provide a determination of the differences between laboratories. Samples of known sediment concentration were submitted to both laboratories and analyzed for TSS. The USGS Branch of Quality Systems prepared two samples with known concentrations (table 9) as part of the Sediment Laboratory Quality Assurance Project (USGS, 2017b). One sample was sent to the USGS Sediment Laboratory, and the other sample was sent to the MDH Environmental Laboratory. The MDH Environmental Laboratory and USGS Sediment Laboratory measured results had a RPD of 8 percent (table 9). The PDs between the known and measured concentrations were 30 and 24 percent (table 9) for the USGS Sediment Laboratory and MDH Environmental Laboratory, respectively. The PDs between the known concentration and measured concentration is most likely a result of the sand content in the sample, which was 15 percent for both samples. 
Table 8. Results of quality-assurance samples for suspended-sediment concentration for samples collected at selected sites in Minnesota, water year 2016.

[EWDI, sample collected with the equal-width-increment or equal-discharge-increment field sampling method; SSC, sample analyzed with the suspended-sediment concentration laboratory analysis method; $\mathrm{mg} / \mathrm{L}$, milligram per liter; RPD, relative percent difference; Minn., Minnesota; USGS, U.S. Geological Survey]

\begin{tabular}{|c|c|c|c|c|c|}
\hline Date & Time & $\begin{array}{c}\text { EWDI-SSC } \\
\text { primary sample } \\
\text { (mg/L) }\end{array}$ & Time & $\begin{array}{c}\text { EWDI-SSC } \\
\text { replicate sample } \\
\text { (mg/L) }\end{array}$ & Absolute RPD \\
\hline \multicolumn{6}{|c|}{ Knife River near Two Harbors, Minn. (USGS station number 04015330) } \\
\hline $3 / 30 / 2016$ & $14: 25$ & 91 & $14: 30$ & 91 & 0 \\
\hline $4 / 19 / 2016$ & $12: 30$ & 20 & $12: 35$ & 19 & 5 \\
\hline $4 / 26 / 2016$ & $13: 00$ & 56 & $13: 05$ & 64 & 13 \\
\hline $5 / 24 / 2016$ & $12: 05$ & 6 & $12: 10$ & 5 & 18 \\
\hline $6 / 7 / 2016$ & $10: 40$ & 18 & $10: 45$ & 18 & 0 \\
\hline $6 / 15 / 2016$ & $08: 15$ & 112 & 08:20 & 113 & 1 \\
\hline $7 / 12 / 2016$ & $14: 50$ & 57 & $14: 55$ & 55 & 4 \\
\hline $8 / 16 / 2016$ & 09:30 & 1 & $09: 35$ & 1 & 0 \\
\hline \multicolumn{6}{|c|}{ Blue Earth River at Highway 169 at Mankato, Minn. (USGS station number 05321995) } \\
\hline $4 / 1 / 2016$ & $10: 45$ & 495 & $10: 50$ & 471 & 5 \\
\hline $4 / 3 / 2016$ & 09:30 & 385 & 09:35 & 407 & 6 \\
\hline $4 / 27 / 2016$ & $14: 10$ & 253 & $14: 15$ & 275 & 8 \\
\hline $5 / 3 / 2016$ & $16: 45$ & 541 & $16: 50$ & 571 & 5 \\
\hline $5 / 10 / 2016$ & 19:05 & 191 & $19: 10$ & 187 & 2 \\
\hline $5 / 24 / 2016$ & $16: 05$ & 152 & $16: 10$ & 148 & 3 \\
\hline $6 / 15 / 2016$ & $17: 25$ & 1,230 & $17: 30$ & 1,380 & 11 \\
\hline $6 / 21 / 2016$ & 09:50 & 328 & 09:55 & 445 & 30 \\
\hline $9 / 26 / 2016$ & $17: 20$ & 685 & $17: 25$ & 680 & 1 \\
\hline \multicolumn{6}{|c|}{ Minnesota River at County Highway 22 in Saint Peter, Minn. (USGS station number 05325300) } \\
\hline $4 / 2 / 2016$ & $16: 30$ & 332 & $16: 35$ & 333 & 0 \\
\hline $5 / 3 / 2016$ & 11:00 & 374 & 11:05 & 346 & 8 \\
\hline $6 / 2 / 2016$ & $11: 30$ & 240 & $11: 35$ & 251 & 4 \\
\hline $6 / 14 / 2016$ & $10: 30$ & 187 & $10: 35$ & 188 & 1 \\
\hline $6 / 21 / 2016$ & $15: 05$ & 324 & $15: 10$ & 340 & 5 \\
\hline $8 / 2 / 2016$ & $11: 30$ & 126 & $11: 35$ & 131 & 4 \\
\hline \multicolumn{6}{|c|}{ Zumbro River at Kellogg, Minn. (USGS station number 05374900) } \\
\hline $4 / 12 / 2016$ & $11: 55$ & 106 & $12: 00$ & 111 & 5 \\
\hline $5 / 11 / 2016$ & $16: 35$ & 64 & $16: 40$ & 62 & 3 \\
\hline $6 / 8 / 2016$ & $13: 45$ & 79 & $13: 50$ & 81 & 3 \\
\hline $6 / 28 / 2016$ & $14: 05$ & 117 & $14: 10$ & 111 & 5 \\
\hline $7 / 14 / 2016$ & $10: 55$ & 95 & 11:00 & 94 & 1 \\
\hline $8 / 11 / 2016$ & $18: 15$ & 2,530 & $19: 25$ & 2,270 & 11 \\
\hline \multirow[t]{2}{*}{$8 / 12 / 2016$} & $06: 20$ & 1,270 & $07: 27$ & 1,220 & 4 \\
\hline & & & & ean absolute RPD & 6 \\
\hline
\end{tabular}

${ }^{\mathrm{a}}$ Calculation of absolute relative percent difference is $\left|\left[\left(x_{1}-x_{2}\right) /\left(\left[x_{1}+x_{2}\right] / 2\right)\right]\right| \times 100$, where $x_{1}$ is the suspendedsediment concentration of the first dataset, and $x_{2}$ is the suspended-sediment concentration of the second dataset, in milligrams per liter. 
Table 9. Results of quality assurance for the total suspended solids laboratory analysis method at two laboratories, water year 2016.

[mg, milligram; L, liter; g, gram; mg/L, milligram per liter; PD, percent difference; USGS, U.S. Geological Survey; MDH, Minnesota Department of Health; RPD, relative percent difference]

\begin{tabular}{|c|c|c|c|c|c|c|c|c|c|}
\hline Laboratory & $\begin{array}{c}\text { Fines } \\
\text { weight } \\
\text { (mg) }\end{array}$ & $\begin{array}{c}\text { Sand } \\
\text { weight } \\
\text { (mg) }\end{array}$ & $\begin{array}{l}\text { Percentage } \\
\text { of fines }\end{array}$ & $\begin{array}{c}\text { Total } \\
\text { sediment } \\
\text { weight } \\
\text { (mg) }\end{array}$ & $\begin{array}{l}\text { Volume of } \\
\text { water } \\
\text { (L) }\end{array}$ & $\begin{array}{c}\text { Bottle with } \\
\text { cap weight } \\
\text { (g) }\end{array}$ & $\begin{array}{c}\text { Known } \\
\text { sample } \\
\text { concentration } \\
\text { (mg/L) }\end{array}$ & $\begin{array}{c}\text { Measured } \\
\text { by lab } \\
\text { concentration } \\
\text { (mg/L) }\end{array}$ & $P^{a}$ \\
\hline USGS & 115.88 & 20.29 & 85 & 136.17 & 0.44756 & 66.7 & 304.2 & 213 & 30 \\
\hline \multirow[t]{2}{*}{$\mathrm{MDH}$} & 115.93 & 20.34 & 85 & 136.27 & 0.44796 & 67.8 & 304.2 & 230 & 24 \\
\hline & & & & & & & & $\mathbf{R P D}^{\mathbf{b}}$ & 8 \\
\hline
\end{tabular}

${ }^{a}$ Calculation of percent difference is $\left[\left(x_{1}-x_{2}\right) / x_{1}\right] \times 100$, where $x_{1}$ is the median concentration of the first dataset, and $x_{2}$ is the median concentration of the second dataset, in milligrams per liter.

${ }^{\mathrm{b}}$ Calculation of absolute relative percent difference is $\left|\left[\left(x_{1}-x_{2}\right) /\left(\left[x_{1}+x_{2}\right] / 2\right)\right]\right| \times 100$, where $x_{1}$ is the suspended-sediment concentration of the first dataset, and $x_{2}$ is the suspended-sediment concentration of the second dataset, in milligrams per liter.

\section{Summary}

Suspended-sediment monitoring entails field sampling and laboratory analysis methods to quantify how much sediment is being transported by streams. Quantitative sediment data are useful for addressing sediment impairments in rivers; however, the field sampling and laboratory analysis methods used to collect suspended sediment data can introduce error into the measured results.

This report documents findings based on river suspendedsediment data collected by the U.S. Geological Survey and Minnesota Pollution Control Agency. Sediment data were collected at eight sites in Minnesota to determine if differences in concentrations between total suspended solids (TSS) and suspended-sediment concentrations (SSC) are from field sampling methods, laboratory analysis methods, or both. Grab field sampling and TSS laboratory analysis methods used by Minnesota were compared to standard U.S. Geological Survey field sampling methods and laboratory analysis methods to determine if methods used by agencies in Minnesota are underrepresenting the amount of suspended sediment in rivers.

Results obtained using grab field sampling and TSS laboratory analysis methods were biased low compared to equal-width-increment or equal-discharge-increment (EWDI), isokinetic, and depth-integrated field sampling and SSC laboratory analysis methods. Differences in field sampling and laboratory analysis methods caused grab and TSS methods to be significantly biased low, and the difference in laboratory analysis methods was slightly greater than the difference in field sampling methods. The largest difference was observed when the assumed most representative field sampling (EWDI) and laboratory analysis (SSC) methods and assumed least representative field sampling (grab) and laboratory analysis (TSS) methods were compared. Differences between concurrent grab samples with one set being analyzed for concentration of fines in the SSCs and the other being analyzed for TSS were the smallest of all comparisons. This smaller difference suggests that grab field sampling and TSS laboratory analysis methods are not sufficiently capturing sand-sized particles.

Grab field sampling and TSS laboratory analyses are biased low because these methods do not effectively capture and measure sand moving through the stream channel. Grab field sampling only incorporates water from the top 1 meter of the water column at a single location in the horizontal stream cross section. In contrast, EWDI samples incorporate water throughout the vertical and horizontal water column, except the bottom 10 centimeters. The occurrence of sand is often greater near the streambed, and sand may not be evenly distributed throughout the horizontal stream cross section. The TSS laboratory analysis method also biases the sample low if the sample includes a high proportion of sand because the heavier sand-sized particles tend to fall out of suspension before a representative subsample can be collected for TSS laboratory analysis. Even though differences are present, the presence of relatively strong correlations between SSC and TSS concentrations provides the opportunity to develop sitespecific relations to address transport processes not captured by grab field sampling and TSS laboratory analysis methods. 


\section{References Cited}

American Society for Testing and Materials [ASTM], 2000, Standard test methods for determining sediment concentration in water samples: West Conshohocken, Pa., American Society for Testing and Materials International, D3977-97, v. 11.02, Water (II), p. 395-400.

Clesceri, L.S., Greenberg, A.E., and Eaton, A.D., eds., 1998, Standard methods for the examination of water and wastewater (20th ed.): Washington, D.C., American Public Health Association, American Water Works Association, Water Environment Federation, [variously paged].

Davis, B.E., and the Federal Interagency Sedimentation Project, 2005, A guide to the proper selection and use of Federally approved sediment and water-quality samplers: U.S. Geological Survey Open File Report 2005-1087, 20 p. [Also available at https://pubs.er.usgs.gov/publication/ ofr20051087.]

Duan, Naihua, 1983, Smearing estimate-A nonparametric retransformation method: Journal of the American Statistical Association, v. 78, no. 383, p. 605-610. [Also available at https://doi.org/10.2307/2288126.]

Edwards, T.K., and Glysson, G.D., 1999, Field methods for measurement of fluvial sediment: U.S. Geological Survey Techniques of Water-Resources Investigations, book 3, chap. C2, 89 p. [Also available at https://pubs.usgs.gov/ twri/twri3-c2/.]

Ellison, C.A., Savage, B.E., and Johnson, G.D., 2014, Suspended-sediment concentrations, loads, total suspended solids, turbidity, and particle-size fractions for selected rivers in Minnesota, 2007 through 2011: U.S. Geological Survey Scientific Investigations Report 2013-5205, 43 p. [Also available at https://doi.org/10.3133/sir20135205].

Glysson, G.D., Gray, J.R., and Conge, L.M., 2000, Adjustment of total suspended solids data for use in sediment studies-Proceeding of the Joint Conference on Water Resource Engineering and Water Resources Planning and Management, Minneapolis, Minn., July 30-August 2, 2000: American Society of Civil Engineers, 10 p. [Also available at https://doi.org/10.1061/40517(2000)270.]

Gray, J.R., Glysson, G.D., Turcios, L.M, and Schwarz, G.E., 2000, Comparability of suspended-sediment concentration and total suspended solids data: U.S. Geological Survey Water-Resources Investigations Report 00-4191, 14 p. [Also available at https://pubs.usgs.gov/wri/wri004191/.]

Guy, H.P., 1969, Laboratory theory and methods for sediment analysis: U.S. Geological Survey Techniques of WaterResources Investigations, book 5, chap. C1, 58 p. [Also available at https://pubs.usgs.gov/twri/twri5c1/.]
Helsel, D.R., and Hirsch, R.M., 2002, Statistical methods in water resources: U.S. Geological Survey Techniques of Water-Resources Investigations, book 4, chap. A3, 522 p. [Also available at https://pubs.usgs.gov/twri/twri4a3/.]

Minnesota Department of Natural Resources [MNDNR], 2017, MNDNR/MPCA cooperative stream gaging: Minnesota Department of Natural Resources, digital data, accessed March 3, 2017, at http://www.dnr.state.mn.us/ waters/csg/index.html.

Minnesota Pollution Control Agency [MPCA], 2009, Total maximum daily load (TMDL) projects: Minnesota Pollution Control Agency website, accessed May 12, 2017, at http:// www.pca.state.mn.us/water/tmdl/index.html.

Minnesota Pollution Control Agency [MPCA], 2017a, Environmental data, accessed May 25, 2017, at https://www.pca. state.mn.us/environmental-data.

Minnesota Pollution Control Agency [MPCA], 2017b, Watershed Pollutant Load Monitoring Network: Minnesota Pollution Control Agency website, accessed August 17, 2017 at https://www.pca.state.mn.us/water/watershed-pollutantload-monitoring-network.

U.S. Army Corps of Engineers, 2006, Sedimentation in the upper Mississippi River Basin: St. Louis, Mo., U.S. Army Corps of Engineers, St. Louis District, 142 p., accessed May 25, 2017, at http://mvs-wc.mvs.usace.army.mil/arec/ Documents/Geomorphology/Sedimentation_Upper_Mississippi_River_Basin_2.pdf.

U.S. Geological Survey [USGS], 1997, Comparison of the suspended-sediment splitting capabilities of the churn and cone splitters: U.S. Geological Survey, Office of Water Quality Memorandum No. 97.06.

U.S. Geological Survey [USGS], 2017a, National Water Information System-USGS water data for the Nation: U.S. Geological Survey database, accessed May 25, 2017, at http://waterdata.usgs.gov/nwis. [Also available at https:// doi.org/10.5066/F7P55KJN.]

U.S. Geological Survey [USGS], 2017b, Sediment Laboratory Quality Assurance Project: U.S. Geological Survey website, accessed June 22, 2017, at https://bqs.usgs.gov/slqa/.

Ward, J.R., and Harr, C.A., eds., 1990, Methods for collection and processing of surface-water and bed-material samples for physical and chemical analyses: U.S. Geological Survey Open-File Report 90-140, 71 p. [Also available at https:// pubs.er.usgs.gov/publication/ofr90140.]

Wilde, F.D., Radtke, D.B., Gibs, Jacob, and Iwatsubo, R.T., eds., 1999, Processing of water samples (ver. 1.0): U.S. Geological Survey Techniques of Water-Resources Investigations, book 9, chap. A5, $125 \mathrm{p}$. [Also available at https://pubs.er.usgs.gov/publication/twri09A5.] 



\section{Appendix}

The final selected log-transformed simple linear regression models are included in the appendix. The files include the definitions, statistics, data, and plots for the simple linear

regression models. The appendix files are available for download at https://doi.org/10.3133/ sir20185023. 
For more information about this publication, contact Director, USGS Upper Midwest Water Science Center 2280 Woodale Drive

Mounds View, MN 55112

(763) 783-3100

For additional information visit https://mn.water.usgs.gov

Publishing support provided by the

Rolla Publishing Service Center 



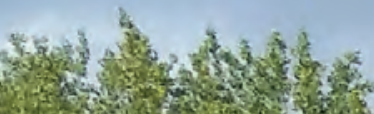

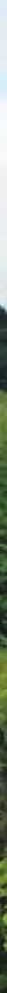

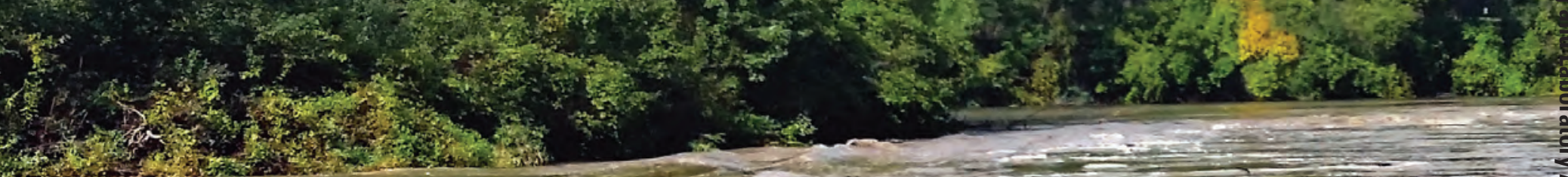

